This is the accepted peer-reviewed manuscript (postprint) of "Assessing pyrite-derived sulfate in the Mississippi River with four years of sulfur and triple-oxygen isotope data" by Bryan Killingsworth (bryan.a.killingsworth(at)gmail.com), Huiming Bao, and Issaku Kohl

The final, copy-edited, version was published in Environmental Science \& Technology and can be found at https://doi.org/10.1021/acs.est.7b05792

This postprint was provided by the publisher as a courtesy for the fulfillment of funder open access requirements and is submitted to EarthArXiv by the authors. 


\section{Assessing pyrite-derived sulfate in the Mississippi River with four years of sulfur and}

triple-oxygen isotope data

Bryan A. Killingsworth ${ }^{\mathrm{a}, \mathrm{b}, *}$, Huiming Bao ${ }^{\mathrm{a}}$, and Issaku E. Kohl $\mathrm{l}^{\mathrm{a}, \$}$

${ }^{\mathrm{a}}$ Department of Geology \& Geophysics, Louisiana State University, Baton Rouge, Louisiana

70803, United States; ${ }^{b}$ IUEM, Laboratoire Géosciences Océan, Université de Bretagne

Occidentale, UMR 6538, Plouzané 29280, France; ${ }^{\$}$ Department of Earth, Planetary, and Space

\section{Abstract} sulfur and oxygen isotope variations reflect their controls such as $\mathrm{SO}_{4}{ }^{2-}$ reduction and re-oxidation, and source mixing. However, unconstrained temporal variability of riverine $\mathrm{SO}_{4}{ }^{2-}$ isotope compositions due to short sampling durations may lead to mischaracterization of $\mathrm{SO}_{4}{ }^{2-}$ sources, particularly for the pyrite-derived sulfate load. We measured the sulfur and triple-oxygen isotopes $\left(\delta^{34} \mathrm{~S}\right.$,
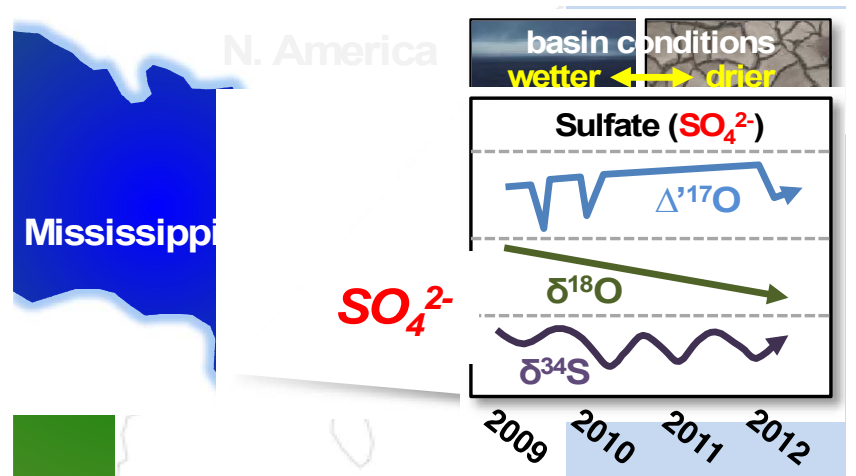
$\delta^{18} \mathrm{O}$, and $\Delta^{, 17} \mathrm{O}$ ) of Mississippi River $\mathrm{SO}_{4}{ }^{2-}$ with biweekly sampling between $2009-2013$ to test isotopic variability and constrain sources. Sulfate $\delta^{34} \mathrm{~S}$ and $\delta^{18} \mathrm{O}$ ranged from $-6.3 \%$ to $-0.2 \%$ and $-3.6 \%$ to $+8.8 \%$, respectively. Our sampling period captured the most severe flooding and drought in the Mississippi River basin since 1927 and 1956, respectively, and a first year of sampling that was unrepresentative of long-term average $\mathrm{SO}_{4}{ }^{2-}$. The $\delta^{34} \mathrm{~S}_{\mathrm{SO} 4}$ data indicate pyritederived $\mathrm{SO}_{4}{ }^{2-}$ sources are $74 \pm 10 \%$ of the Mississippi River sulfate budget. Furthermore, pyrite oxidation is implicated as the dominant process supplying $\mathrm{SO}_{4}{ }^{2-}$ to the Mississippi River, whereas the $\Delta^{, 17} \mathrm{O}_{\mathrm{SO} 4}$ data shows $18 \pm 9 \%$ of oxygen in this sulfate is sourced from air $\mathrm{O}_{2}$. 


\section{Introduction}

The characterization of riverine chemical fluxes today is important for establishing natural baselines for understanding the magnitude of human impact on chemical cycles and

37 interpreting the rock record of biogeochemical changes in Earth's past. For the surface sulfur

38 cycle, which is closely linked to the carbon and oxygen cycles over long time scales, its most

39 significant flux is riverine sulfate input to the ocean ${ }^{1}$. Natural variations in the magnitude and

40 isotopic composition of the sulfate flux reflects the exposures and weathering rates of sulfide and

41 sulfate minerals in rocks ${ }^{2}$. Meanwhile, human activities, such as the mining and burning of fossil

42 fuels like coal, can increase riverine sulfate fluxes four-fold and alter sulfate's sulfur isotope

43 composition on a large scale, such as in the Mississippi River ${ }^{3}$. Thus, studies of the continental

44 sulfur cycle have made efforts to constrain riverine $\mathrm{SO}_{4}{ }^{2-}$ fluxes and isotope compositions

45 globally ${ }^{4-7}$ and in large $e^{8-10}$ and small ${ }^{11-14}$ rivers. Riverine studies have suggested that global

46 sulfate budgets may underrepresent the pyrite-derived sulfate flux, which is particularly

47 important for sulfur and carbon weathering budgets ${ }^{9,15}$.

48 An advantage of riverine chemical studies is their integration of spatial and temporal

49 scales. Depending on the research focus, sampling campaigns of different durations can be

50 designed according to the basin size and its assumed variability, to constrain temporal variation

51 with multi-year sampling, or to reveal spatial variations. However, a lack of temporal constraints

52 on $\mathrm{SO}_{4}{ }^{2-}$ isotopes may result in biased conclusions about sulfate sources and processes. For

53 example, the average isotope compositions of inputs are needed to construct stable isotope

54 mixing models to constrain sulfate sources in individual rivers and in models of the global

55 surface sulfur cycle. A low frequency or short duration of sampling may bias model results

56 towards one season or an anomalous year. Only some riverine sulfate isotope studies last a year ${ }^{8}$ 
$57^{10,16-18}$ or longer $^{19-26}$, and out of the rivers that were monitored for $\geq 1$ year, just the Yangtze, 58 Indus, Oldman, and Kalix are $>5,000 \mathrm{~km}^{2}$. For these long-term studies, the average ranges for $59 \quad \delta^{34} \mathrm{~S}$ and $\delta^{18} \mathrm{O}$ are $\sim 5 \%$ and have no correlation with catchment size. Thus there are insufficient 60 temporal constraints on riverine $\mathrm{SO}_{4}{ }^{2-}$ isotope variability over large, and continental, spatial 61 scales. For example, significant variability was shown within one year of Yangtze River sulfate 62 data where the ranges of $\delta^{34} \mathrm{~S}_{\mathrm{SO} 4}$ and $\delta^{18} \mathrm{O}_{\mathrm{SO} 4}$ were respectively $9.5 \%$ and $8.9 \%{ }^{10}$. In another 63 example from a highly cited study, $85 \% \pm 5 \%$ of sulfate flux in the relatively pristine Mackenzie

64 River in Canada was attributed to pyrite oxidation ${ }^{9}$. This assessment was based on stable isotope $65\left(\delta^{34} \mathrm{~S}\right.$ and $\left.\delta^{18} \mathrm{O}\right)$ mixing of sulfate sources for 20 samples taken throughout the basin at one time, 66 with only one sample recovered from the river mouth that could represent the output to the 67 ocean. The respective $\delta^{34} \mathrm{~S}$ and $\delta^{18} \mathrm{O}$ had significant spatial variation of $28.3 \%$ and $12.6 \%$, 68 respectively, and the temporal variability was undetermined. While the conclusion appears

69 robust that most of the sulfate in the Mackenzie is pyrite-derived, it remains difficult to know if 70 the estimate of pyrite-derived sulfate flux is applicable to the long term. Regardless, the 71 estimation of pyrite-derived sulfate loads, and its natural and anthropogenic partitioning, is not a 72 trivial task due to large $\delta^{34} \mathrm{~S}$ and $\delta^{18} \mathrm{O}$ ranges and their overlaps with other sulfate sources. High 73 loadings of pyrite-derived sulfate may result in large ranges of $\delta^{34} \mathrm{~S}_{\mathrm{SO} 4}$ and $\delta^{18} \mathrm{O}_{\mathrm{SO} 4}$, which are

74 commonly used as sulfate source tracers. Regardless, a lack of significant temporal variability, 75 and a coupled response related to sources, are implicitly assumed for $\delta^{34} \mathrm{~S}_{\mathrm{SO} 4}$ and $\delta^{18} \mathrm{O}_{\mathrm{SO} 4}$. 


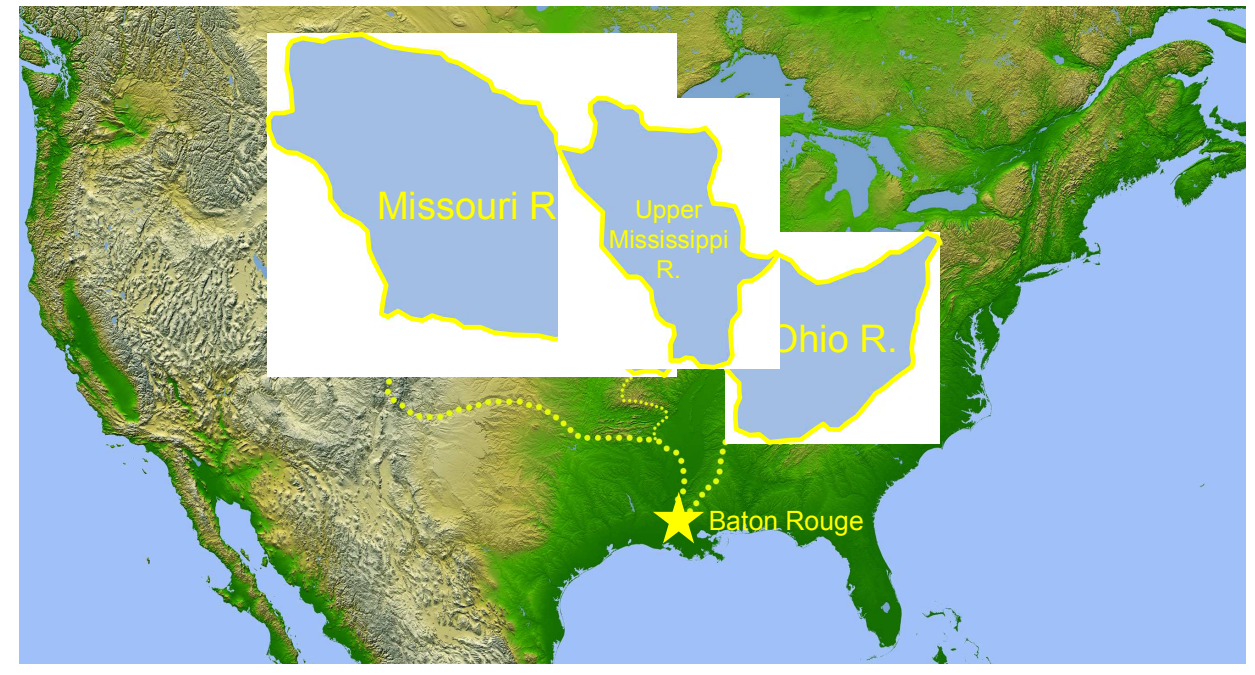

77 Figure 1. The Mississippi River basin within the contiguous United States, with the Missouri and Ohio River sub-basins and the sampling location for this study at Baton Rouge, Louisiana identified. Image is modified from the original from NASA/JPL ${ }^{27}$.

To test $\mathrm{SO}_{4}{ }^{2-}$ isotopic variability over time and constrain sources, we target the

82 Mississippi River. The Mississippi, Yangtze, and Amazon Rivers are the top three rivers for

83 sulfate flux to the ocean worldwide ${ }^{28}$. The Mississippi River basin (Figure 1) covers $\sim 37 \%$ of the

84 contiguous United States ${ }^{29}$ and is the largest river system in North America. The Mississippi

85 River basin has been heavily altered by human activities such as agriculture $\left(65 \%\right.$ by area $\left.^{30}\right)$,

86 dams and reservoirs in the semi-arid west, and levee systems prevalent in the lower Mississippi

87 River. Bedrock sources of sulfate within the Mississippi River include abundant pyrite-bearing

88 shales in its western reaches, evaporite exposures, and mine drainage from coalbeds within sub-

89 basins in the west (Missouri River) and east (Ohio River). The Mississippi River $\delta^{34} \mathrm{~S}_{\mathrm{SO} 4}$ average

90 was previously used in a stable isotope mixing model to characterize sulfate sources ${ }^{3}$, whereas

91 the full time series $\delta^{34} \mathrm{~S}_{\mathrm{SO} 4}, \delta^{18} \mathrm{O}_{\mathrm{SO} 4}$, and $\Delta^{, 17} \mathrm{O}_{\mathrm{SO} 4}$ data from 2009-2013 are reported here. In the

92 previous study, it was estimated that human activities account for $75 \%$ of the Mississippi River

$93 \mathrm{SO}_{4}{ }^{2-}$ flux and have increased the average Mississippi River $\delta^{34} \mathrm{~S}_{\mathrm{SO} 4}$ from $-5 \%$ to $-2.7 \%$, and it 
94 was concluded that the more typical scenario should be the opposite - where most rivers should

95 instead display decreasing $\delta^{34} \mathrm{~S}_{\mathrm{SO} 4}$ due to human influence. The distinctly low $\delta^{34} \mathrm{~S}_{\mathrm{SO} 4}$ of the

96 Mississippi River was interpreted as the result of a high input of sulfate from the weathering of

97 pyrite. Mississippi River sulfate was partitioned into sources from coalmine drainage (47\%),

98 natural and anthropogenic rock weathering (37\%), atmospheric sulfur (15\%), and fertilizer (1\%).

99 In the present study, Mississippi River $\mathrm{SO}_{4}{ }^{2-}$ isotope compositions are compared to ion

100 concentrations, discharge, and temperature from the $\mathrm{USGS}^{31}$ and discharge from the USACE ${ }^{32}$.

101 While average Mississippi River $\delta^{34} \mathrm{~S}_{\mathrm{SO} 4}$ made the previous source partitioning possible, four

102 years of data from $2009-2013$ permits us to examine the full variability and controls on $\delta^{34} \mathrm{~S}_{\mathrm{SO}}$,

$103 \delta^{18} \mathrm{O}_{\mathrm{SO} 4}$, and $\Delta^{, 17} \mathrm{O}_{\mathrm{SO} 4}$ and attempt to more finely resolve the pyrite-derived sulfate load here.

105 Materials and Methods

106 Mississippi River water was collected biweekly or at greater frequency during the period

$107 \quad 03 / 11 / 09$ to $01 / 17 / 13$ for $\delta^{34} \mathrm{~S}_{\mathrm{SO} 4}, \delta^{18} \mathrm{O}_{\mathrm{SO} 4}$, and $\Delta^{, 17} \mathrm{O}_{\mathrm{SO} 4}$ measurements. River water samples

108 were collected at the east bank of the Mississippi River at Baton Rouge or St. Francisville,

109 Louisiana, USA and immediately processed or refrigerated for later processing. Our sampling

110 locations near Baton Rouge, Louisiana integrate the main sub-basins of the Mississippi River

111 except for the Red and Ouachita Rivers, and thus here the $\mathrm{SO}_{4}{ }^{2-}$ flux to the ocean for $\sim 37 \%$ of

112 the contiguous United States is accounted for. ${ }^{29}$ A few additional samples were collected from

113 the sub-basin upper Ohio River at Tell City, Indiana to compare against the main Mississippi

114 River. All samples were treated with the DDARP method, yielding purified $\mathrm{BaSO}_{4}{ }^{33}$. 
115 The riverine dissolved sulfates were analyzed for their isotope $\delta^{34} \mathrm{~S}_{\mathrm{SO} 4}, \delta^{18} \mathrm{O}_{\mathrm{SO} 4}$, and

$116 \Delta^{, 17} \mathrm{O}_{\mathrm{SO} 4}$ per the methods here with additional details in the supporting information (chapter 1).

117 The classical isotope notation is used here:

$$
\delta \equiv R_{\text {sample }} / R_{\text {standard }}-1
$$

119 Where $R$ is the mole ratio of ${ }^{18} \mathrm{O} /{ }^{16} \mathrm{O},{ }^{17} \mathrm{O} /{ }^{16} \mathrm{O}$, or ${ }^{34} \mathrm{O} /{ }^{32} \mathrm{O}$ and reported in units per mille $(\times$

$1201000 \%$ ) with respect to the international isotope standards VSMOW or VCDT for $\delta^{18} \mathrm{O}$ and $\delta^{34} \mathrm{~S}$, 121 respectively. We note that the linear "capital delta" definition is

$$
\Delta^{17} \mathrm{O} \equiv \delta^{17} \mathrm{O}-\mathrm{C} \times \delta^{18} \mathrm{O}
$$

123 where $\mathrm{C}$ is an arbitrary reference slope ${ }^{34}$. Here we use a logarithmic definition,

$$
\begin{gathered}
\Delta^{, 17} \mathrm{O} \equiv \delta^{, 17} \mathrm{O}-\mathrm{C} \times \delta{ }^{18} \mathrm{O}, \text { where } \\
\delta^{, 1 \mathrm{x}} \mathrm{O}=\ln \left(\delta^{1 \mathrm{x}} \mathrm{O}+1\right)=\ln \left(R_{\text {sample }} / R_{\text {standard }}\right) .
\end{gathered}
$$

126 The ${ }^{1 \mathrm{x}} \mathrm{O}$ in equation (4) refers to the isotope ${ }^{18} \mathrm{O}$ or ${ }^{17} \mathrm{O}$, and $\Delta^{, 17} \mathrm{O}$ is reported in \%o with respect

127 to the standard VSMOW (Fig. S1). The choice of the reference slope $\mathrm{C}$ in equation (3) is 0.5305 , 128 which benefits inter-species comparison ${ }^{34}$. All measurements for $\Delta^{, 17} \mathrm{O}$ were done on samples 129 converted to $\mathrm{O}_{2}$ and run on a Thermo Finnigan MAT 253 isotope ratio mass spectrometer 130 (IRMS) at Louisiana State University (LSU). The raw average of replicate $\delta^{17} \mathrm{O}_{\mathrm{SO} 4}$ and $\delta^{18} \mathrm{O}_{\mathrm{SO} 4}$ 131 values (in \%o) are available in Tables S1 and S2 for re-normalization to other reference frames of 132 choice. The $\delta^{34} \mathrm{~S}_{\mathrm{SO} 4}$, measurements were conducted at the University of Maryland and Indiana 133 University using an Elemental Analyzer coupled to an IRMS. For $\delta^{18} \mathrm{O}_{\mathrm{SO} 4}$, analysis was done at 134 LSU using a high temperature conversion Elemental Analyzer (TCEA) coupled to a Thermo 135 Finnigan MAT 253 IRMS in continuous flow mode. Analytical errors for standards and sample 136 duplicates for $\delta^{34} \mathrm{~S}_{\mathrm{SO} 4}, \delta^{18} \mathrm{O}_{\mathrm{SO} 4}$, and $\Delta^{, 17} \mathrm{O}_{\mathrm{SO} 4}$ are $\pm 0.3 \%$, $\pm 0.5 \%$, and $\pm 0.05 \%$ respectively. 
To determine trends and seasonality of sulfate, monthly averages of the isotope data were

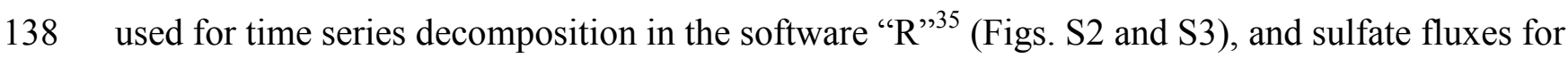

139 the main Mississippi River and sub-basins were compared. Additional available data is used

140 from continuously monitored water discharge, ion concentration, temperature, and other

141 parameters at St. Francisville, Louisiana ${ }^{31}$, where for that location the main stem water discharge

142 of the Mississippi is represented by the Tarbert Landing, MS and Knox Landing, LA sites

143 monitored by the USACE ${ }^{32}$. Mississippi River sub-basin sulfate concentration and river

144 discharge data is used from the Missouri River at Hermann, MO, Upper Mississippi below

145 Grafton, IL, and Ohio River at Metropolis, IL, which are monitored by the USGS ${ }^{31}$.

146 Sulfate flux estimates for the Mississippi River and its sub-basins use the daily river

147 discharge data with sulfate concentrations reported by the USGS for the respective sites given

148 above. To estimate daily sulfate fluxes for the purposes of matching datasets and making mixing

149 models, sulfate concentrations are interpolated from the approximately once-monthly

150 measurements from the USGS, and matched with daily water discharge reported by the USACE

151 and USGS. Sulfate flux estimates should be considered to have lower resolution than the isotope

152 data due to interpolation from approximate once-monthly concentration measurements.

\section{Results}

155 Mississippi River $\mathrm{SO}_{4}{ }^{2-}$ varies from -6.3 to $-0.2 \%$ and averages $-2.7 \%$ for ${ }^{34} \mathrm{~S}_{\mathrm{SO} 4}$,

156 from -3.6 to $8.8 \%$ and averages $3.4 \%$ for $\delta^{18} \mathrm{O}_{\mathrm{SO} 4}$, and ranges -0.19 to $-0.01 \%$ with an average

157 of $-0.09 \%$ for $\Delta{ }^{, 17} \mathrm{O}_{\mathrm{SO} 4}$ (Figure 2, Table S1). Time series decomposition reveals seasonality in

$158 \delta^{34} \mathrm{~S}_{\mathrm{SO} 4}$ with an amplitude of $3 \%$, with minima in late summer, and a $\delta^{18} \mathrm{O}_{\mathrm{SO} 4}$ decrease of $5 \%$ 
159 from 2009 to 2013 (Figure S2), with $\Delta^{, 17} \mathrm{O}_{\mathrm{SO} 4}$ exhibiting more secular variation. Histograms of

$160 \delta^{34} \mathrm{~S}_{\mathrm{SO} 4}$ and $\delta^{18} \mathrm{O}_{\mathrm{SO} 4}$ are shown in the supporting information (Fig. S3).

161 Sulfate for the period 01/27/11 to 06/01/11 from the Upper Ohio River sub-basin ranged 162 from -0.3 to $1.6 \%$ and averaged $0.3 \%$ for $\delta^{34} \mathrm{~S}_{\mathrm{SO} 4}$ and ranged 1.4 to $2.9 \%$ and averaged $2.1 \% \mathrm{o}$ 163 for $\delta^{18} \mathrm{O}_{\mathrm{SO} 4}($ Table S2).

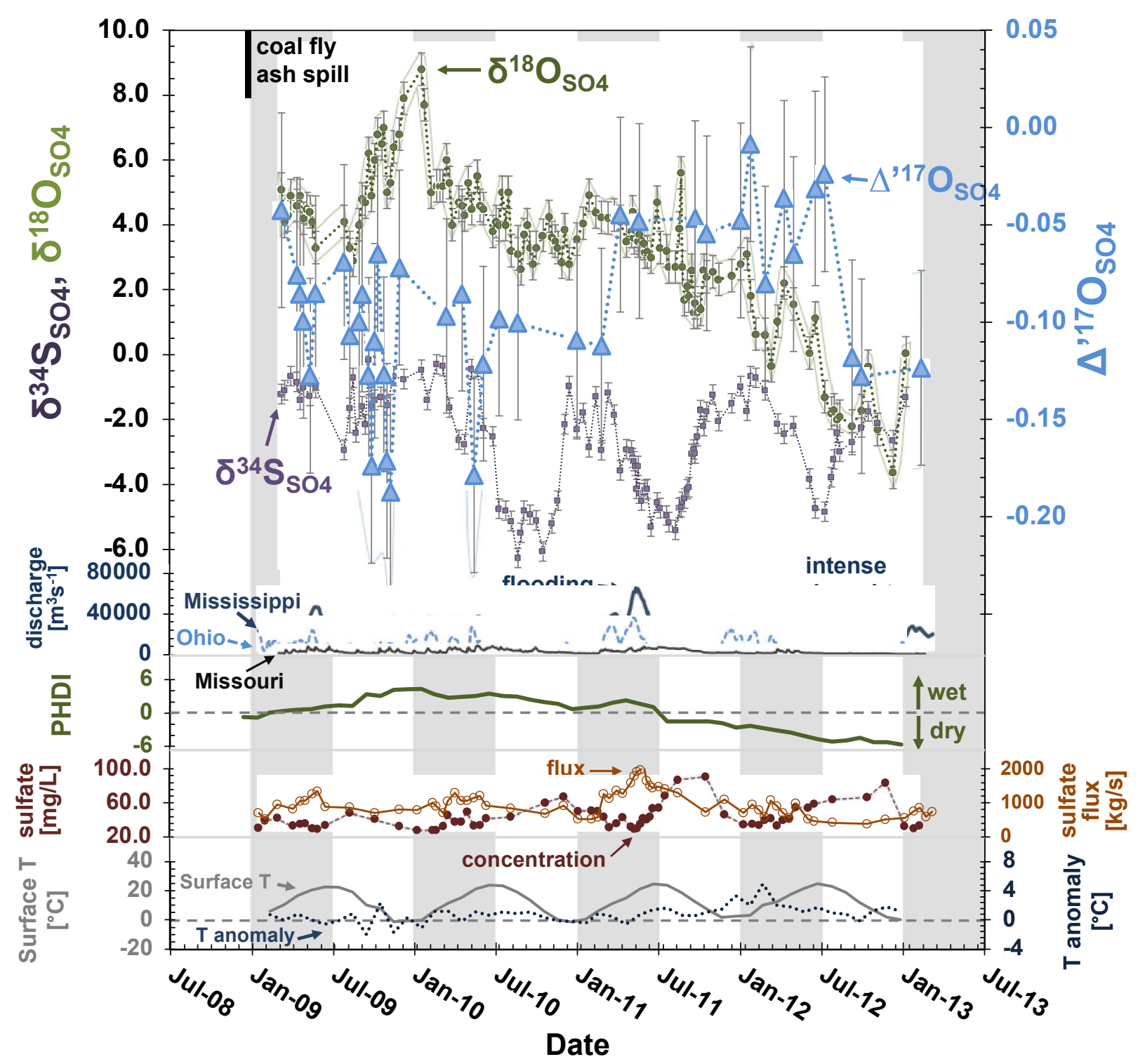


168 Figure 2. Mississippi River sulfate isotope $\delta^{34} \mathrm{~S}_{\mathrm{SO} 4}, \delta^{18} \mathrm{O}_{\mathrm{SO} 4}$, and $\Delta{ }^{, 17} \mathrm{O}_{\mathrm{SO} 4}$ data from this study 169 plotted with available data for surface temperature, temperature anomaly (based on monthly 170 averages from 1901-2000), and Palmer Hydrological Drought Index (PHDI) for the contiguous 171 United States $^{36}$, river basin discharge data ${ }^{31,32}$, and sulfate concentration ${ }^{31}$. Sulfate flux is 172 calculated from discharge data and sulfate concentration. Analytical errors for isotope data are 173 shown as error bars and envelopes. Significant events are noted: 1) the Kingston Fossil Plant coal 174 fly ash slurry spill on 12/22/08, 2) historical flooding (the most intense since 1927) in the spring 175 of 2011, and 3) historical drought (strongest since 1956) in the summer to fall of 2012.

\section{Discussion}

\section{Constraining temporal variability}

Mississippi River sulfate had higher average $\delta^{34} \mathrm{~S}_{\mathrm{SO} 4}$ and an attenuated seasonality in

1822009 that appear unrepresentative of the long term. The year 2009 may be atypical for two

183 reasons: one of the largest coal fly ash spills in United States history occurred in December 2008

184 where 4.1 million cubic meters of coal ash was released within a tributary of the Mississippi

185 River $^{37}$, and the summer of 2009 was wetter than average (see PHDI in Fig. 2). Mississippi River

186 sulfate concentrations did not increase due to the coal ash spill although there were modest

187 increases in the tributary where the spill occurred ${ }^{37}$. The lack of a clear sulfate signal in the

188 Mississippi River from such a spill suggests that widespread coal ash impoundments leaking in

189 the humid southeastern United States ${ }^{38}$ may contribute diffuse but large fluxes of sulfate that are

190 difficult to quantify. The mixing model used in the previous study was based on the 4-year

191 Mississippi River $\delta^{34} \mathrm{~S}_{\mathrm{SO} 4}$ average of $-2.7 \%$ and gave a solution of $-5 \%$ for the $\delta^{34} \mathrm{~S}_{\mathrm{SO} 4}$ of

192 natural (pre-anthropogenic) sulfate ${ }^{3}$. Natural Mississippi River $\delta^{34} \mathrm{~S}_{\mathrm{SO} 4}$ would be $-0.8 \%$ from the

193 same model if the 2009 Mississippi River $\delta^{34} \mathrm{~S}_{\mathrm{SO} 4}$ average of $-1 \%$ is used. And again, a solution

194 based on the lowest Mississippi River $\delta^{34} \mathrm{~S}_{\mathrm{SO} 4}$ of $-6.3 \%$ from $08 / 26 / 2010$ would imply that

195 natural Mississippi River $\delta^{34} \mathrm{~S}_{\mathrm{SO} 4}$ was $-14.0 \%$. This exercise shows how source estimates can 
196 significantly differ from the long term when based on an unrepresentative year or a one-time 197 "snapshot".

199 Low $\boldsymbol{\delta}^{\mathbf{3 4}} \mathbf{S}$ values of Mississippi River sulfate

200 The likely source of Mississippi River sulfate with low $\delta^{34} \mathrm{~S}_{\mathrm{SO} 4}$ indicated from the

201 Missouri River sub-basin is the weathering of pyrite in rocks deposited during the transgression

202 of a Cretaceous-age epicontinental seaway ${ }^{3}$ which are now exposed in western and upper reaches

203 of the Mississippi River basin ${ }^{39}$. The $\delta^{34} \mathrm{~S}$ of pyrites in Cretaceous shales can span a wide range,

204 with reported values between $+16.7 \%$ to $-34.7 \%$ but mostly negative with a mean at $-19.7 \%{ }^{40}$.

205 The implication for respectively lower and higher $\delta^{34} \mathrm{~S}_{\mathrm{SO} 4}$ of the Missouri River and Ohio River

206 is consistent with the seasonal and spatial patterns in $\delta^{34} \mathrm{~S}$ from zebra mussels across the

207 Mississippi River basin during 1997-1998 ${ }^{41}$. The zebra mussel sulfur is sourced from riverine

208 sulfate but slightly fractionated, for example at Baton Rouge the reported mussel $\delta^{34} \mathrm{~S}$ was near

$209-4 \%$ versus the average $\delta^{34} \mathrm{~S}_{\mathrm{SO} 4}$ around $-3 \%$ from our study, with their comparison suggesting

210 that Mississippi River sulfate end members have not changed significantly over the past $\sim 20$

211 years.

212

\section{Mass balance of pyrite-derived sulfate}

214 Here we provide a more detailed Mississippi River sulfate mass balance that expands on

215 the previous work using the $\delta^{34} \mathrm{~S}_{\mathrm{SO} 4}$ average ${ }^{3}$. The $\delta^{34} \mathrm{~S}$ of sulfate from rock weathering of shale 216 pyrite and evaporite (excluding mine drainage), which here we will call $\delta^{34} \mathrm{~S}_{\mathrm{RW}}$, was previously

217 estimated as $-6.5 \%$, where the sulfate from natural and anthropogenically enhanced rock

218 weathering were assumed to have the same $\delta^{34} \mathrm{~S}$ value ${ }^{3}$. We adopt $\delta^{34} \mathrm{~S}$ values of $20 \%$ for 
219 evaporite ${ }^{9}$ and $-17 \%$ for pyrite from marine shales ${ }^{42}$, for $\delta^{34} \mathrm{~S}_{\mathrm{E}}$ and $\delta^{34} \mathrm{~S}_{\mathrm{Py}}$ respectively. Despite a 220 typically wide range in pyrite sulfur isotope compositions, such as a $\sim 50 \%$ range in Cretaceous

221 pyrite $\delta^{34} \mathrm{~S}$ data ${ }^{40}$, the strong $\delta^{34} \mathrm{~S}$ difference between average marine evaporite and pyrite is

222 forgiving when using estimated values to partition their mass balance. With the given

223 constraints, the mixing equation becomes:

$$
\delta^{34} \mathrm{~S}_{\mathrm{RW}}=f_{\mathrm{Py}} * \delta^{34} \mathrm{~S}_{\mathrm{Py}}+\left(1-f_{\mathrm{Py}}\right) * \delta^{34} \mathrm{~S}_{\mathrm{E}}
$$

225 The mass balance of pyrite and evaporite can then be solved for the unknown fraction of pyrite, $226 f_{\mathrm{Py}}$, which is determined as 0.72 with evaporite being the remainder. Thus, the sulfate load from 227 rock weathering in the Mississippi River is $72 \%$ pyrite-derived sulfate and $28 \%$ evaporite sulfate, 228 or a respective $26.5 \%$ and $11 \%$ of the total Mississippi River sulfate budget (Table S3). A scaling 229 of coal production to riverine sulfate $\operatorname{load}^{15}$ was previously used to estimate the contribution of 230 mine drainage pyrite-derived sulfate. The result was, out of a total flux of $27.8 \mathrm{Tg} \mathrm{SO}_{4}{ }^{2-} \mathrm{yr}^{-1}$

231 from the Mississippi River, sulfate from mine drainage accounted for $47 \%$ and its average $\delta^{34} \mathrm{~S}$ 232 value was estimated as $-1.8 \% 0^{3}$. Thus, the sulfate load from natural and anthropogenically 233 enhanced weathering of shale pyrite and pyrite weathering in mine drainage is $74 \pm 10 \%$, or 20.6

$234 \mathrm{Tg} \mathrm{SO}_{4}{ }^{2-} \mathrm{yr}^{-1}$. Under such heavy loads of pyrite-derived sulfate, the oxygen isotopes of

235 Mississippi River sulfate should strongly reflect variations in the ambient water oxygen source 236 and the pathway of pyrite oxidation.

\section{Seasonal variations}

239 The differences in sulfur isotope compositions of average bedrocks in Mississippi River 240 sub-basins, and the dominance of pyrite-derived sulfate, may explain the $\delta^{34} \mathrm{~S}_{\mathrm{SO} 4}$ seasonality as 241 well as the lack of the same in $\delta^{18} \mathrm{O}_{\mathrm{SO} 4}$ (Figs. 2 and 3), all despite a heavy anthropogenic 
242 overprint. A global comparison of riverine sulfate reveals smaller ranges of average $\delta^{18} \mathrm{O}_{\mathrm{SO} 4}$ with

243 high contributions from evaporite sulfate and a larger range of average $\delta^{18} \mathrm{O}_{\mathrm{SO} 4}$ in rivers with

244 higher amounts of pyrite-derived sulfate (shale pyrite and mine drainage sources) (Fig. 3a). Also

245 observed in figure 3a, rivers with high pyrite-derived sulfate loads have $\delta^{18} \mathrm{O}_{\mathrm{SO} 4}$ corresponding to

246 local meteoric water differences, whereas sulfate from the North American Mackenzie, Oldman,

247 and Mississippi Rivers plot with respectively lower to higher $\delta^{18} \mathrm{O}_{\mathrm{SO} 4}$ values that reflect the

248 correlation of lower $\delta^{18} \mathrm{O}_{\text {water }}$ with higher latitudes. The Mississippi River $\delta^{34} \mathrm{~S}_{\mathrm{SO} 4}$ and $\delta^{18} \mathrm{O}_{\mathrm{SO} 4}$

249 data indicate the strong signature of pyrite-derived sulfate as compared to evaporite sulfate, and

250 mixing of two sources that are significantly different in their $\delta^{34} \mathrm{~S}_{\mathrm{SO} 4}$ but not in their $\delta^{18} \mathrm{O}_{\mathrm{SO} 4}$ (Fig.

$2513 b)$. The Ohio and Missouri River sub-basins contribute a respective $33 \%$ and $41 \%$ of average

252 Mississippi River sulfate flux during the study period. The average Mississippi River $\delta^{34} \mathrm{~S}_{\mathrm{SO} 4}$ and

$253 \delta^{18} \mathrm{O}_{\mathrm{SO} 4}$ for the upper ranges of Ohio and Missouri sulfate flux contributions are plotted in figure

$2543 \mathrm{~b}$ and indicate that the most important source of ${ }^{34} \mathrm{~S}$-depleted sulfate in the Mississippi River

255 comes from the Missouri River sub-basin ${ }^{3}$. Source mixing in the Mississippi River is also

256 apparent in a bimodal distribution of $\delta{ }^{34} \mathrm{~S}_{\mathrm{SO} 4}$ data with modes at around $-1 \%$ and $-5 \%$ (Fig.

$257 \mathrm{~S} 3$ ). During the periods of seasonally low $\delta^{34} \mathrm{~S}_{\mathrm{SO} 4}$ the Missouri River accounts for up to $\sim 80 \%$ of

258 total Mississippi River sulfate flux (Fig. S4). Sulfate measurements from 01/27/11 to 06/01/11

259 from the upper Ohio River at Tell City, Indiana (Table S2) show that the Ohio has higher

260 average $\delta^{34} \mathrm{~S}_{\mathrm{SO} 4}(0.3 \%$ ) compared to the Mississippi River (-3.2\%o) during the same interval.

261 Meanwhile, from figure $3 \mathrm{~b}$ we estimate that the difference in $\delta^{18} \mathrm{O}_{\mathrm{SO} 4}$ between Ohio and

262 Missouri river sulfate is less than $1 \%$. 

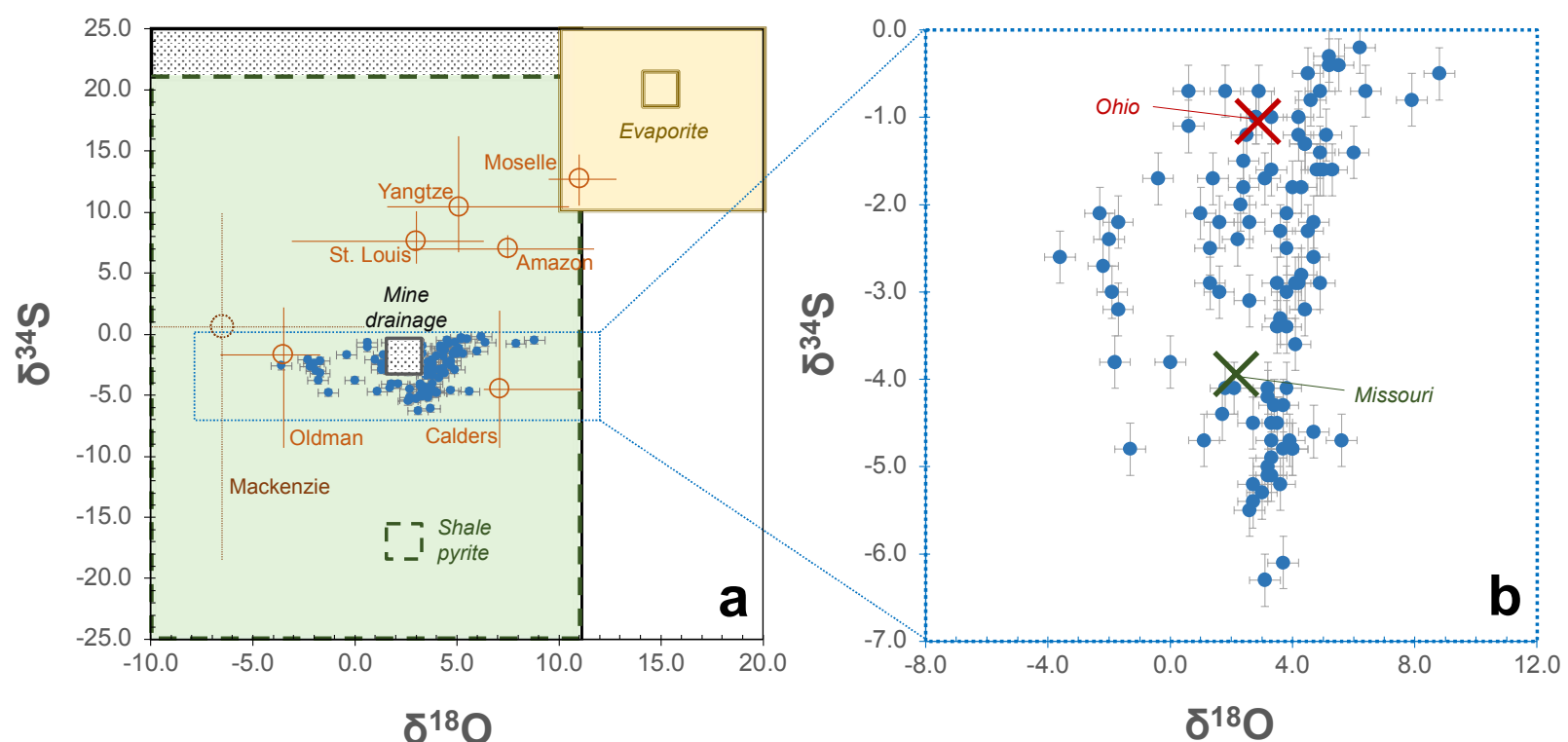

Figure 3. Sulfate $\delta^{34} \mathrm{~S}$ is plotted against $\delta^{18} \mathrm{O}$ for this study, selected rivers, and expected ranges of riverine sulfate sources. In plot (a), sulfate data for the Mississippi River from this study (filled circles) are shown along with previously published river averages and their ranges (open circles and error bars for ranges) $9,10,22,24,43-45$, and the important rock sources of sulfate of evaporites $^{9}$, shale pyrite ${ }^{42}$, mine drainage ${ }^{3}$, with their averages (open squares) and respective ranges (shaded boxes). Note that the Mackenzie River average is from spatial data while all other riverine sulfate averages are from time series. The average $\delta^{18} \mathrm{O}_{\mathrm{SO} 4}$ of sulfate derived from oxidation of pyrite in shales and mine drainage in (a), are estimated from oxygen sources of average Mississippi River water $\left(-6.6 \%{ }^{46}\right)$ and air $\mathrm{O}_{2}\left(23.5 \%{ }^{47}\right)$, with a typical fractionation between sulfate and water of $9 \%{ }^{48}$, and the resulting sulfate oxygen having a source ratio $3 / 4$ water and $1 / 4$ air $\mathrm{O}_{2}{ }^{49}$. The estimated $\delta^{18} \mathrm{O}_{\mathrm{SO} 4}$ ranges $(\sim-20 \%$ to $11 \%$ ) for sulfate from pyrite oxidation and mine drainage assume that such sulfate can approach a $100 \%$ water oxygen end member $\left(\sim-20 \%\right.$ at its lowest for US river waters $\left.{ }^{50}\right)$; and on the high end, with US river waters up to $\sim-2 \% 0^{50}$, sulfate could reach up to $11 \%$ with the aforementioned sulfate-water fractionation factor and oxygen source ratio. Plot (b) shows an expanded view of the Mississippi River sulfate data and its averages (large symbols) for the upper $25 \%$ of flux contributions from the Ohio and Missouri Mississippi River sub-basins with respect to the Mississippi River sulfate total.

\section{Differential response of $\delta^{34} \mathrm{~S}_{\mathrm{SO} 4}$ and $\delta^{18} \mathrm{O}_{\mathrm{SO} 4}$ to sulfate origin}

Riverine sulfate oxygen isotope $\delta^{18} \mathrm{O}$ has been used previously to help constrain the

287 straightforward as $\delta^{34} \mathrm{~S}_{\mathrm{SO} 4}$ because $\delta^{34} \mathrm{~S}_{\mathrm{SO} 4}$ is able to more faithfully retain source compositions 
288 while $\delta^{18} \mathrm{O}_{\mathrm{SO} 4}$ is prone to variable kinetic isotope effects and replacement of its original oxygen ${ }^{49}$

28952 . The oxygen isotopes of $\mathrm{SO}_{4}{ }^{2-}$ reflect a combination of its sources that are mainly water and

290 air $\mathrm{O}_{2}\left(\right.$ where $\delta^{18} \mathrm{O}_{\mathrm{O} 2}=23.5 \%{ }^{47}$, and US surface waters range $\sim-20 \%$ to $-2 \%$ in $\delta^{18} \mathrm{O}_{\mathrm{H} 2 \mathrm{O}}{ }^{50}$ ),

291 oxygen isotope fractionation factors, the net effect of bacterial sulfate reduction, and the

292 pathways of oxidation from sulfide to sulfate. Sulfate generated from the abiotic or biological

293 oxidation of pyrite have $\delta{ }^{34} \mathrm{~S}_{\mathrm{SO} 4}$ compositions that are very similar to their pyrite source and

$294 \delta^{18} \mathrm{O}_{\mathrm{SO} 4}$ compositions linked to the $\delta^{18} \mathrm{O}$ of the ambient water source and the oxidation

295 pathway ${ }^{53,54}$. Similarly, during the mineralization of biomass the re-oxidation of sulfur will

296 affect the resulting $\delta{ }^{18} \mathrm{O}_{\mathrm{SO} 4}$ and leave $\delta^{34} \mathrm{~S}$ relatively unchanged between its sulfur source and

297 the resulting sulfate. Biological sulfur cycling via bacterial sulfate reduction (BSR) and

298 subsequent re-oxidation of the product sulfide to sulfate (for example, in marine environments 75

299 to $90 \%$ is re-oxidized ${ }^{7}$ ) is one of the most significant controls on the mix of oxygen sources in

$300 \mathrm{SO}_{4}{ }^{2-}$ in freshwater and marine environments. Due to BSR, the concentration of remaining $\mathrm{SO}_{4}{ }^{2-}$

301 decreases and becomes more enriched in ${ }^{18} \mathrm{O}$ and ${ }^{34} \mathrm{~S}^{55}$. During so-called cryptic sulfur cycling,

302 however, BSR can operate without affecting sulfate concentration or $\delta^{34} \mathrm{~S}_{\mathrm{SO} 4}$ but a quantitative

303 re-oxidation of sulfide to sulfate results in replacement of sulfate oxygen and thus an effect on

$304 \delta^{18} \mathrm{O}_{\mathrm{SO} 4}{ }^{56}$. The comparison of sulfate concentrations, $\delta^{18} \mathrm{O}_{\mathrm{SO} 4}$, and $\delta^{34} \mathrm{~S}_{\mathrm{SO} 4}$ in the Mississippi

305 River, where pyrite-derived sulfate composes $74 \pm 10 \%$ of the budget, may not show conclusive

306 evidence of BSR in the sense of residual sulfate decreasing in concentration and increasing in

$307 \delta^{18} \mathrm{O}_{\mathrm{SO} 4}$ and $\delta^{34} \mathrm{~S}_{\mathrm{SO} 4}$. Indeed, the Mississippi River sulfate concentration changes appear related

308 to dilution effects, where spring snowmelt and precipitation result in lower sulfate concentration

309 without a clear signal in $\delta^{18} \mathrm{O}_{\mathrm{SO} 4}$ and $\delta^{34} \mathrm{~S}_{\mathrm{SO} 4}$ (Fig. 2). 
During 2009-2013, Mississippi River $\delta^{18} \mathrm{O}_{\mathrm{SO} 4}$, in contrast to its $\delta^{34} \mathrm{~S}_{\mathrm{SO}}$, does not respond

311 seasonally. The $\delta^{18} \mathrm{O}_{\mathrm{SO} 4}$ shows a general decreasing trend concomitant with increasing drought

312 (Figs. 2 and 4) and a strong peak in the beginning of 2010. The $\delta^{18} \mathrm{O}_{\mathrm{SO} 4}$ response appears to be

313 basin-wide behavior across the Mississippi River, as compared to the seasonal control on sub-

314 basin sulfate input reflected in $\delta^{34} \mathrm{~S}_{\mathrm{SO} 4}$ variations. First, although it composes just $15 \%$ of the

315 Mississippi River sulfate budget ${ }^{3}$, the oxygen isotope composition of atmospheric sulfate input is

316 probably replaced, as consistent with results from a 36-year study in Hubbard Brook where

317 internal cycling of atmospheric sulfate occurred during a residence time of 9 years ${ }^{57,58}$.

318 Furthermore, there are significant variations in the oxygen isotopes of river water between

319 Mississippi River sub-basins ${ }^{50}$ and this should register in the Mississippi River that has

320 significant pyrite-derived sulfate that takes most of its oxygen from water. However, water data

321 for the Ohio and Upper Mississippi ${ }^{59}$, and Missouri ${ }^{60}$ Rivers, indicates respective average

$322 \delta^{18} \mathrm{O}_{\text {water }}$ for these rivers of $-7.5 \%$ o, $-8.2 \%$, and $-9 \%$. The average oxygen isotope differences

323 are a maximum of $1.5 \%$ between Mississippi River sub-basin river waters and this will be

324 reflected in their pyrite-derived sulfate. Thus, while the $\delta^{34} \mathrm{~S}_{\mathrm{SO} 4}$ response is strong, the $\delta^{18} \mathrm{O}_{\mathrm{SO} 4}$

325 responds weakly to the geographic origin of sulfate sources in the Mississippi River (Fig. 3b).

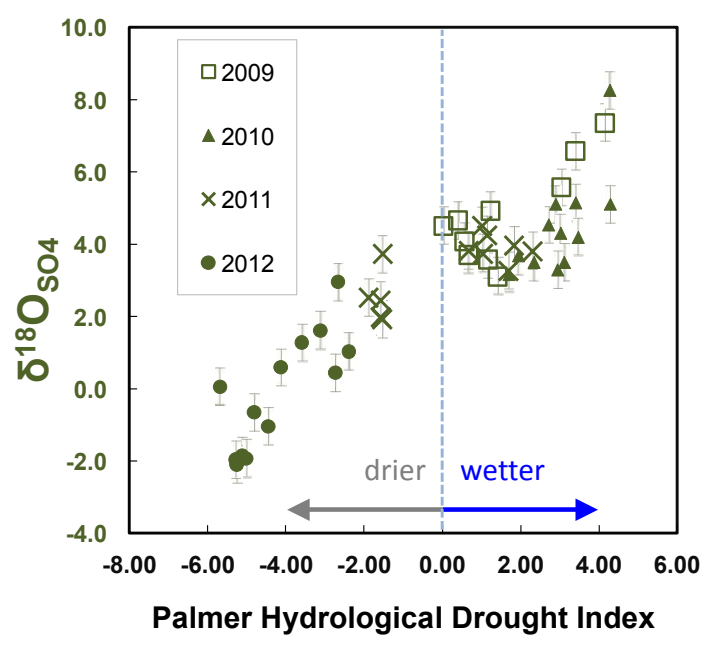


327 Figure 4. Monthly averages of Mississippi River sulfate $\delta^{18} \mathrm{O}$, from this study, cross-plotted against monthly Palmer Hydrological Drought Index (PHDI) for the contiguous United States. ${ }^{36}$ Palmer drought indices indicate moisture conditions, with negative and positive values indicating dry and wet anomalies, respectively. ${ }^{61}$ In this case, Mississippi River sulfate $\delta^{18} \mathrm{O}$ has a positive correlation with the PHDI, where lower and higher $\delta^{18} \mathrm{O}_{\mathrm{SO} 4}$ correspond to increasing drought and wetter conditions, respectively.

Implications of the trend in $\delta^{18} \mathrm{O}_{\mathrm{SO} 4}$

The trend of decreasing Mississippi River $\delta^{18} \mathrm{O}_{\mathrm{SO} 4}$ over 2009-2013 occurs with increasing

337 average drought and surface temperature in the contiguous United States and this suggests

338 possible mechanisms for the $\delta^{18} \mathrm{O}_{\mathrm{SO} 4}$ response. Monthly averages of Mississippi River sulfate

$339 \delta^{18} \mathrm{O}$ correlate strongly $\left(\mathrm{R}^{2}=0.82\right.$, linear regression $)$ with the Palmer Hydrological Drought

340 Index (PHDI) (Fig. 4). A "hydrological drought" condition is where surface and ground water

341 availability is lower than average due to meteorological drought, as caused by anomalously low

342 precipitation that can in turn be caused by temperature anomalies ${ }^{62}$. The PHDI can be considered

343 an indicator of environmental response to precipitation input, and as such the PHDI changes

344 more slowly than precipitation ${ }^{63}$. The strong correlation between Mississippi River $\delta^{18} \mathrm{O}_{\mathrm{SO} 4}$ and

345 PHDI, but lack of correlations between $\delta^{18} \mathrm{O}_{\mathrm{SO} 4}$ and changes in sulfate flux between Mississippi

346 River sub-basins or other chemical parameters (e.g., USGS-monitored concentration of redox-

347 sensitive elements such as As and V, water temperature, and dissolved oxygen) suggests that it is

348 a balance between sulfate from more recent surface runoff versus sulfate from groundwater that

349 controls Mississippi River $\delta^{18} \mathrm{O}_{\mathrm{SO} 4}$. It is possible that oxygen source for low $\delta^{18} \mathrm{O}_{\mathrm{SO} 4}$ could be

350 from the northwestern region of the Mississippi River basin, as streamwaters in the upper

351 Missouri River area can range down to a $\delta^{18} \mathrm{O}_{\mathrm{H} 2 \mathrm{O}}$ of $-18 \%{ }^{50}$. However, Mississippi River sulfate

352 should also show the low $\delta^{34} \mathrm{~S}_{\mathrm{SO} 4}$ values expected from Missouri River sulfate input if it was

353 more significant during drought but this does not occur (Fig. 2). As reviewed by Van Stempvoort 
354 and Krouse ${ }^{48}$, with few exceptions sulfate oxygen isotopes are more ${ }^{18} \mathrm{O}$-enriched than the 355 ambient water in which the sulfate originates due to fractionation between sulfate and water $356\left(\delta^{18} \mathrm{O} \approx+9 \%\right.$ ) and the variably kinetic incorporation of ${ }^{18} \mathrm{O}$-enriched oxygen from air $\mathrm{O}_{2}\left(\delta^{18} \mathrm{O}=\right.$ $\left.35723.5 \%{ }^{47}\right)$. The ${ }^{18} \mathrm{O}$-enrichment of sulfate relative to water is due to rapid oxygen exchange 358 between sulfite and water, where sulfite is an intermediate during sulfide oxidation to sulfate, 359 and sulfite is shown to be $9.5 \pm 0.8 \%{ }^{18} \mathrm{O}$-enriched versus water under typical experimental 360 conditions $^{64}$. While there is some correlation between $\delta^{18} \mathrm{O}_{\mathrm{SO} 4}$ and $\delta^{34} \mathrm{~S}_{\mathrm{SO} 4}$ during wetter 361 conditions (wet PHDI, Fig. S6), during dry conditions there is no such correlation despite nearly 362 the same range of $\delta^{34} \mathrm{~S}_{\mathrm{SO} 4}$ as during wetter conditions in the Mississippi River. Here we suspect a 363 difference in oxidation pathways for pyrite-derived sulfate in surface versus groundwater 364 environments, where more extensive weathering of pyrites in groundwater results in a greater 365 proportion of water oxygen in sulfate as compared to pyrite oxidation in more surficial 366 environments. Thus, a greater proportion of groundwater sulfate sources, attended by lower $367 \delta^{18} \mathrm{O}_{\mathrm{SO} 4}$, may be represented in the river during drought conditions as compared to normal or 368 high flow periods. As summarized by Taylor and Wheeler, $1993^{65}$, two reactions are typically 369 used to describe pyrite oxidation to sulfate:

$$
\begin{aligned}
& \mathrm{FeS}_{2}+7 / 2 \mathrm{O}_{2}+\mathrm{H}_{2} \mathrm{O} \rightarrow \mathrm{Fe}^{2+}+2 \mathrm{SO}_{4}{ }^{2-}+2 \mathrm{H}^{+} \\
& \mathrm{FeS}_{2}+14 \mathrm{Fe}^{3+}+8 \mathrm{H}_{2} \mathrm{O} \rightarrow 15 \mathrm{Fe}^{2+}+2 \mathrm{SO}_{4}{ }^{2-}+16 \mathrm{H}^{+}
\end{aligned}
$$

372 Where reaction (7) is rate-limited by the oxidation of $\mathrm{Fe}^{2+}$ by $\mathrm{O}_{2}$ in the reaction:

$$
\mathrm{Fe}^{2+}+1 / 4 \mathrm{O}_{2}+\mathrm{H}^{+} \rightarrow \mathrm{Fe}^{3+}+1 / 2 \mathrm{H}_{2} \mathrm{O}
$$

374 In experiments ${ }^{53}$, and in natural systems ${ }^{65}$, it has been observed that the oxidation of pyrite under 375 submersed and alternating wet/dry conditions results in sulfate with $\delta^{18} \mathrm{O}_{\mathrm{SO} 4}$ that is around $2 \%$ to $37618 \%$ higher than that of ambient water $\delta^{18} \mathrm{O}_{\text {water, }}$ a scenario that was used to estimate the ranges 
377 of pyrite-derived sulfate for the Mississippi River shown in figure $3 \mathrm{a}$. This $\delta^{18} \mathrm{O}$ offset between

378 pyrite-derived sulfate and water can tend towards a more restricted range of about 5\%o to $12 \%$ o in

379 neutral waters and goes towards smaller offsets (down to $4 \%$ ) under submersed, sterile, and

380 anaerobic conditions and larger offsets (up to $\sim 18 \%$ ) under wet/dry, with sulfide-oxidizing

381 bacteria present, and aerobic conditions ${ }^{65}$. Mississippi River sulfate during drier PHDI conditions

382 may have an even greater proportion of oxygen from water because it is derived from pyrite

383 preferentially oxidized under reaction (7). Alternatively, changing Mississippi River hydrologic

384 conditions may exert a control on an expression of cryptic sulfur cycling within the basin, and

385 thus characteristically affect $\delta^{18} \mathrm{O}_{\mathrm{SO} 4}$ and not $\delta^{34} \mathrm{~S}_{\mathrm{SO} 4}{ }^{56}$, with $\delta^{18} \mathrm{O}_{\mathrm{SO} 4}$ possibly shifting to lower

386 values in accordance with a changing locus of sulfide oxidation from more to less aerated

387 environments, however the mechanisms behind cryptic sulfur cycling are still poorly understood.

\section{$389 \Delta^{, 17} \mathbf{O}_{\text {SO4 }}$ constraints on sulfate oxygen sources}

Variations in $\Delta^{, 17} \mathrm{O}_{\mathrm{SO} 4}$ can help to differentiate sources, formation pathways, and

391 processes affecting riverine sulfate. However, $\Delta{ }^{, 17} \mathrm{O}_{\mathrm{SO} 4}$ in surface waters is an underdeveloped

392 tracer, with presently only one riverine $\Delta^{17} \mathrm{O}_{\mathrm{SO} 4}$ study available ${ }^{66}$. Here we note that $\Delta^{17} \mathrm{O}$ (eq. 2 )

393 is used to describe triple oxygen isotopes in general, but we report the logarithmic form $\Delta^{, 17} \mathrm{O}$

394 (eq. 3). The difference between $\Delta^{, 17} \mathrm{O}$ and $\Delta^{17} \mathrm{O}$ is very small for measurements not far from the

395 origin, for example within error of each other for the Mississippi River sulfate data (Fig. S1).

396 Generally, sulfate has positive $\Delta^{17} \mathrm{O}$ values when originated as secondary atmospheric sulfate,

397 and slightly negative values when formed via oxidation of reduced sulfur ${ }^{67}$. The positive $\Delta^{17} \mathrm{O}$

398 range of atmospheric sulfate, $0.14 \%$ to $1.43 \%$ in northern hemisphere precipitation ${ }^{68,69}$, is

399 inherited from ozone and/or hydrogen peroxide ${ }^{70}$. This ${ }^{17} \mathrm{O}$-enrichment from atmospheric $\mathrm{SO}_{4}{ }^{2-}$ 
400 input, which is $\sim 15 \%$ of the Mississippi River sulfate budget ${ }^{3}$, is likely lost via replacement with 401 oxygen from ambient water and/or air $\mathrm{O}_{2}$ during sulfate reduction and sulfide re-oxidation within 402 biologically active surface environments. Likewise, the sulfate generated during oxidative 403 weathering of sulfides, such as pyrite and organic sulfur, will incorporate its oxygen from 404 ambient water $\left(\Delta^{, 17} \mathrm{O}=-0.03\right.$ to $+0.11 \%$ in the Northern Hemisphere $\left.{ }^{71}\right)$ and air $\mathrm{O}_{2}\left(\Delta^{, 17} \mathrm{O}=\right.$ $405-0.47 \%{ }^{47}$ ) with effects from associated fractionation factors.

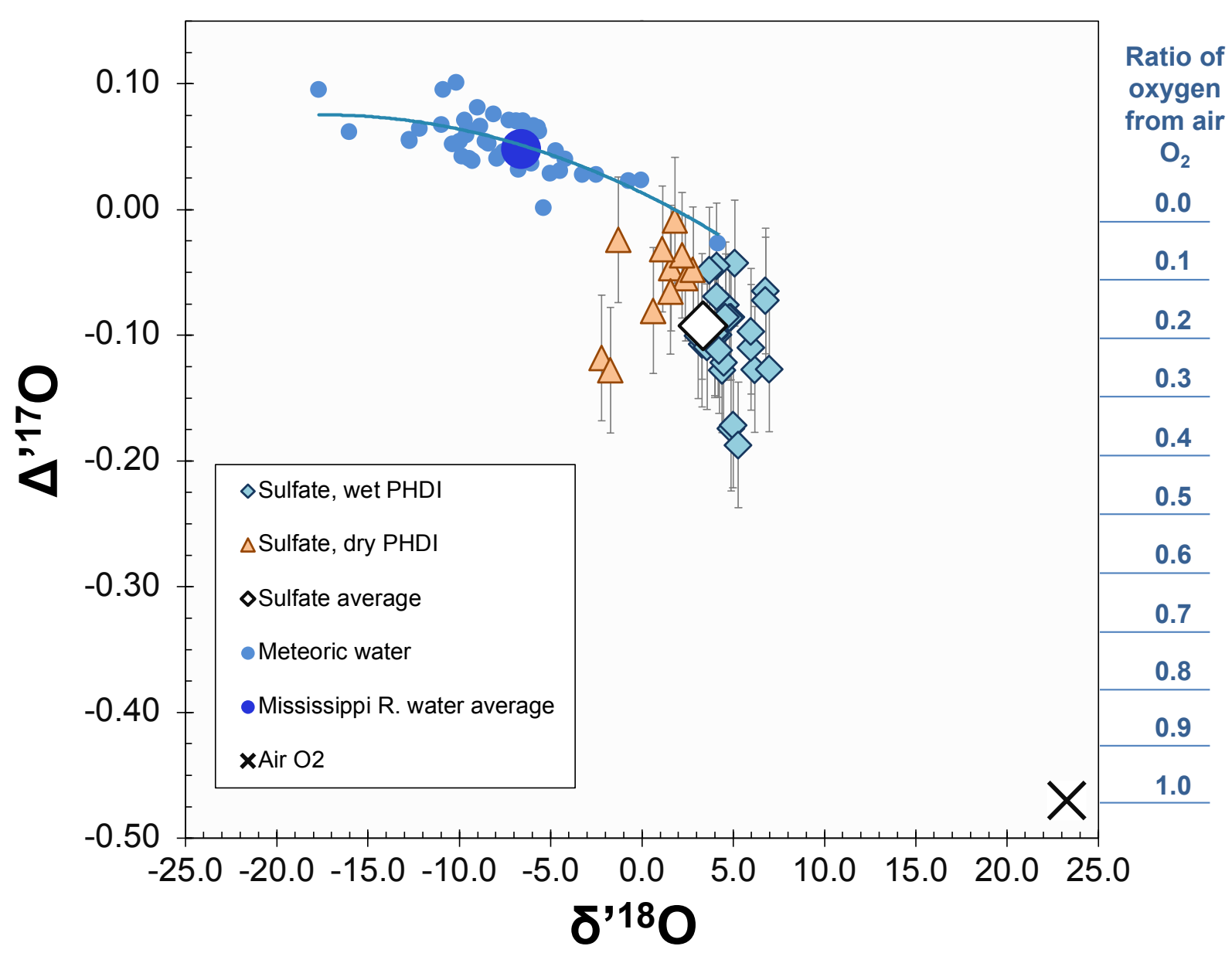

407 Figure 5. Plot of triple oxygen isotopes reported in \%o VSMOW. The $\Delta^{, 17} \mathrm{O}$ uses a 0.5305 reference slope and is cross-plotted against $\delta^{, 18} \mathrm{O}$. All sulfate data are from the Mississippi River from this study and are shown with values of its potential oxygen sources meteoric water ${ }^{71}$ and 410 air $\mathrm{O}_{2}{ }^{47}$. The average Mississippi River $\delta^{18} \mathrm{O}_{\text {water }}$ is $-6.6 \%$ from the lower Mississippi ${ }^{59}$ and here its $\Delta^{17} \mathrm{O}$ is inferred. The sulfate data is divided according to wet or dry conditions in the 413 Mississippi River basin (wet or dry PHDI). The dashed lines schematically represent possible mixing paths between Mississippi River sulfate oxygen end members, average Mississippi River 
414 water and air $\mathrm{O}_{2}$. The boundaries of this mixing path are based on previous work on $\delta^{18} \mathrm{O}$

415 fractionations between sulfate and water and sulfate and air $\mathrm{O}_{2}$ during pyrite oxidation ${ }^{53,65}$. The

416 location and direction of the arrows indicates starting points for mixing between oxygen end

417 members when the fractionation factors between sulfate and water and sulfate and air $\mathrm{O}_{2}$ are

418 considered.

A very simplified view of the triple oxygen isotope composition of Mississippi River

421 sulfate is linear mixing between average Mississippi River water and air $\mathrm{O}_{2}$. It is tempting to use

422 the $\delta^{18} \mathrm{O}$ difference between sulfate and ambient water to assess the relative contributions of

423 water and air $\mathrm{O}_{2}$ oxygen to sulfate, but the evidence cautions against this. The oxidation of

424 sulfide to sulfate involves multiple kinetic steps that can result in sulfate with a $\delta^{18} \mathrm{O}$ value even

425 lower than that of ambient water ${ }^{48,49,72}$. Therefore using $\delta^{18} \mathrm{O}$ to estimate water and air $\mathrm{O}_{2}$

426 oxygen contributions to sulfate may be unreliable, particularly when the sample populations are

427 small. In the case of $\Delta^{, 17} \mathrm{O}_{\mathrm{SO} 4}$, it is less prone to the same kinetic effects observed in $\delta^{18} \mathrm{O}_{\mathrm{SO}}$. The

428 use of $\Delta^{, 17} \mathrm{O}_{\mathrm{SO} 4}$ to assess air $\mathrm{O}_{2}$ is relevant for understanding the ancient Earth atmosphere in the

429 geological past via sulfate in rocks ${ }^{67}$ and thus characterizing the $\Delta^{, 17} \mathrm{O}$ tracer in modern riverine

430 sulfates is a necessary calibration step. Under the reference frame we use for $\Delta^{, 17} \mathrm{O}$ (where the

431 slope $\mathrm{C}=0.5305$ in eq. 3 ), sulfate $\Delta^{, 17} \mathrm{O}$ versus $\delta{ }^{, 18} \mathrm{O}$ will normally show negative correlation

432 when the oxygen sources are water and air $\mathrm{O}_{2}$ (Fig. 5). As shown in figure 5, the oxygen isotope

433 offset between pyrite-derived sulfate and water that was observed in $\delta^{18} \mathrm{O}_{\mathrm{SO} 4}$ from submersed

434 (closer to water values) and alternating wet/dry experiments (further from water values) ${ }^{53}$ and in

435 natural settings ${ }^{65}$ appears to also be expressed in the added triple oxygen isotope dimension of

$436 \Delta{ }^{, 17} \mathrm{O}$. Previous pyrite oxidation experiments using $\Delta^{17} \mathrm{O}$ revealed that a stoichiometric average

$4371 / 4$ of oxygen in pyrite-derived $\mathrm{SO}_{4}{ }^{2-}$ came from air $\mathrm{O}_{2}$ with the remaining $3 / 4$ oxygen coming

438 from ambient water ${ }^{49}$. The triple oxygen isotope compositions of water follow a predictable array

439 due to Rayleigh distillation ${ }^{71}$. We can use this meteoric water array and the relatively large $\Delta^{, 17} \mathrm{O}$ 
440 difference between it and air $\mathrm{O}_{2}$ to our advantage and estimate if a given sulfate oxygen isotope 441 composition has an almost entirely water oxygen source by simply checking its closeness to 442 meteoric water in triple oxygen isotope space (Fig. 5). We assume that the highest Mississippi 443 River $\Delta^{, 17} \mathrm{O}_{\mathrm{SO} 4}(-0.01 \%$, Fig. 5) closely represents the sulfate end member with $100 \%$ water 444 oxygen source because its location in triple oxygen isotope space matches well with the sulfate 445 predicted from pyrite oxidation, and its attendant oxygen sulfate-water $\delta^{18} \mathrm{O}$ offset, with $100 \%$ 446 water oxygen sourced from average Mississippi River water. The $100 \%$ air $\mathrm{O}_{2}$ sulfate end 447 member is represented by the value of modern air $\mathrm{O}_{2}, \Delta^{, 17} \mathrm{O}=-0.47 \%{ }^{47}$. With these Mississippi 448 River sulfate oxygen water and air $\mathrm{O}_{2}$ end members, a mixing equation can be constructed as 449 follows:

$$
\Delta{ }^{, 17} \mathrm{O}_{\mathrm{SO} 4}=f_{\mathrm{airO} 2} * \Delta^{, 17} \mathrm{O}_{\mathrm{airO} 2}+\left(1-f_{\mathrm{airO} 2}\right)^{*} \Delta^{, 17} \mathrm{O}_{\text {water }}
$$

451 Between these end members, the fraction of air $\mathrm{O}_{2}$ in Mississippi River sulfate $\left(f_{\text {airO2 } 2}\right)$ is 0.18.

452 Thus, with respect to $\Delta^{, 17} \mathrm{O}$ and including 1 standard deviation error, $18 \pm 9 \%$ of Mississippi 453 River sulfate oxygen is shown to be sourced from air $\mathrm{O}_{2}$ (Fig. S7). This result is consistent with $45474 \%$ of Mississippi River sulfate being from pyrite-derived sulfate. With the assumptions that an 455 average of $25 \%$ of oxygen from air $\mathrm{O}_{2}$ is in pyrite-derived sulfate ${ }^{49}$, and that all other sulfate 456 sources sum to $\Delta^{, 17} \mathrm{O}=0.00 \%$, then $0.74 * 0.25=0.19$, nearly identical, though perhaps 457 coincidentally so, to the ratio of air $\mathrm{O}_{2}$ oxygen in Mississippi River sulfate determined via $\Delta^{, 17} \mathrm{O}$.

\section{Modeling the Mississippi River sulfate $\delta^{34} \mathrm{~S}, \delta^{18} \mathrm{O}$, and $\Delta^{, 17} \mathrm{O}$ time series}

$460 \quad$ Finally, the Mississippi River sulfate isotope time series were modeled with mixing of 461 sulfate fluxes between three sub-basins and an input term for PHDI and respectively assigned 462 isotope values. Twelve inputs are reduced to four variables that are further constrained with our 
463 sulfate measurements from the Ohio River, published freshwater mussel sulfur isotopes from

464 within the Mississippi River basin, published water oxygen isotope data, and our updated

465 Mississippi River sulfate source partitioning. The mixing model is as follows:

$$
\delta^{\mathrm{xx}} \mathrm{Z}_{\mathrm{Model}}=f_{\mathrm{Flux}} *\left(f_{\mathrm{MSR}} * \delta^{\mathrm{xx}} \mathrm{Z}_{\mathrm{MSR}}+f_{\mathrm{OR}} * \delta^{\mathrm{xx}} \mathrm{Z}_{\mathrm{OR}}+f_{\mathrm{UMR}} * \delta^{\mathrm{xx}} \mathrm{Z}_{\mathrm{UMR}}\right)+f_{\mathrm{PHDI}} *\left(f_{\mathrm{Wet}} * \delta^{\mathrm{xx}} \mathrm{Z}_{\mathrm{Wet}}+\right.
$$

$$
\left.f_{\text {Dry }} * \delta^{\mathrm{xx}} \mathrm{Z}_{\text {Dry }}\right)
$$

468 Here, the $\delta^{\mathrm{xx}} \mathrm{Z}$ refers to the isotope parameter $\delta^{34} \mathrm{~S}, \delta^{18} \mathrm{O}$, or $\Delta^{, 17} \mathrm{O}$; and $\delta^{\mathrm{xx}} \mathrm{Z}_{\text {Model }}$ is the daily 469 modeled output for Mississippi River $\delta^{34} \mathrm{~S}_{\mathrm{SO} 4}, \delta^{18} \mathrm{O}_{\mathrm{SO} 4}$, or $\Delta^{, 17} \mathrm{O}_{\mathrm{SO} 4}$ during the measured study 470 period (03/11/09 to 01/01/13). The proportion of influence from the mixing of sulfate fluxes

471 from Mississippi River sub-basins versus the continental-scale forcing due to overall

472 hydrological conditions is balanced between $f_{\text {Flux }}$ and $f_{\text {PHDI }}$, where $f_{\text {PHDI }}=1-f_{\text {Flux }}$. For the mix of

473 sub-basin sulfate fluxes, $f_{\mathrm{MSR}}, f_{\mathrm{OR}}$, and $f_{\mathrm{UMR}}$ are the respective sulfate flux ratios and $\delta^{\mathrm{xx}} \mathrm{Z}_{\mathrm{MSR}}$,

$474 \delta^{\mathrm{xx}} \mathrm{Z}_{\mathrm{OR}}$, and $\delta^{\mathrm{xx}} \mathrm{Z}_{\mathrm{UMR}}$ are the respective isotope values $\left(\delta^{34} \mathrm{~S}_{\mathrm{SO} 4}, \delta^{18} \mathrm{O}_{\mathrm{SO} 4}\right.$, or $\left.\Delta^{, 17} \mathrm{O}_{\mathrm{SO} 4}\right)$ for the

475 Missouri, Ohio, and Upper Mississippi river sub-basins of the Mississippi River. The sub-basin

476 fluxes were determined by taking daily water discharge data and matching them with sulfate

477 concentrations that were interpolated, from measurements taken approximately monthly, to give

478 daily values. Then, the ratios for sub-basin sulfate fluxes were each sub-basin's sulfate flux

479 versus their combined sum, here using the mix of sulfate flux between three sub-basins to

480 represent the whole Mississippi River. The difference in sulfate flux between the averages

481 determined from the lower Mississippi River and the summed three sub-basins was 6\% during

482 the study period, and thus the flux contribution from the middle Mississippi River is neglected in

483 the model. The influence of hydrological conditions represented by the Palmer Hydrological

484 Drought Index is split into "wet" and "dry" components in order to assign different respective

485 "wet" and "dry" isotope values $\left(\delta^{\mathrm{xx}} Z_{\text {Wet }}\right.$ and $\left.\delta^{\mathrm{xx}} Z_{\text {Dry }}\right)$. The PHDI $f_{\text {Wet }}$ and $f_{\text {Dry }}$ components use 
486 reported monthly PHDI interpolated to give daily PHDI, which is then scaled to make a ratio 487 where maximum dry PHDI during the study period is equal to 1 , and wet PHDI is the difference, 488 where $f_{\mathrm{Wet}}=1-f_{\text {Dry. }}$. The model input variables are then $\delta^{\mathrm{xx}} Z_{\mathrm{MSR}}, \delta^{\mathrm{xx}} \mathrm{Z}_{\mathrm{OR}}, \delta^{\mathrm{xx}} \mathrm{Z}_{\mathrm{UMR}}$ and $f_{\mathrm{Flux}}$. The 489 input values are explored for feasible Mississippi River $\delta^{34} \mathrm{~S}_{\mathrm{SO} 4}, \delta^{18} \mathrm{O}_{\mathrm{SO} 4}$, or $\Delta{ }^{, 17} \mathrm{O}_{\mathrm{SO} 4}$ by testing 490 for the average of sum daily modeled outputs against the average of sum measured values, the 491 correlation between daily model outputs and measured values, and good agreement between the 492 curves of measured and modeled time series data. The best-fitting model outputs are shown in 493 figure 6 and the global values for model parameters are in the supporting information (Table S4). 494 The Mississippi River $\delta^{34} \mathrm{~S}_{\mathrm{SO} 4}$ time series model is feasible if the Ohio River has higher $\delta^{34} \mathrm{~S}_{\mathrm{SO} 4}$ 495 than the Missouri River and it is almost entirely controlled by their balance of sulfate flux input 496 as compared to influence from basinwide wetter or drier conditions, as modeled via PHDI.

497 Mississippi River $\delta^{18} \mathrm{O}_{\mathrm{SO} 4}$ is described well in our model with our estimated contribution of $74 \%$ 498 pyrite-derived sulfate dominating sulfate flux and thus resulting in $\delta^{18} \mathrm{O}_{\mathrm{SO} 4}$ that is dominated by a 499 water oxygen source best represented by the average ambient Mississippi River river water $\delta^{18} \mathrm{O}$ 500 and a changing oxidation pathway that can be simulated by the PHDI term in the model, whereas 501 only $26 \%$ of the Mississippi River $\delta^{18} \mathrm{O}_{\mathrm{SO} 4}$ is due to the balance of sulfate fluxes from the three 502 sub-basins used in the model. The Mississippi River $\Delta^{, 17} \mathrm{O}_{\mathrm{SO} 4}$ modeling follows the same 503 forcings as $\delta^{18} \mathrm{O}_{\mathrm{SO} 4}$ but there is an additional transient component in the real data which our 504 model is unable to recreate. 

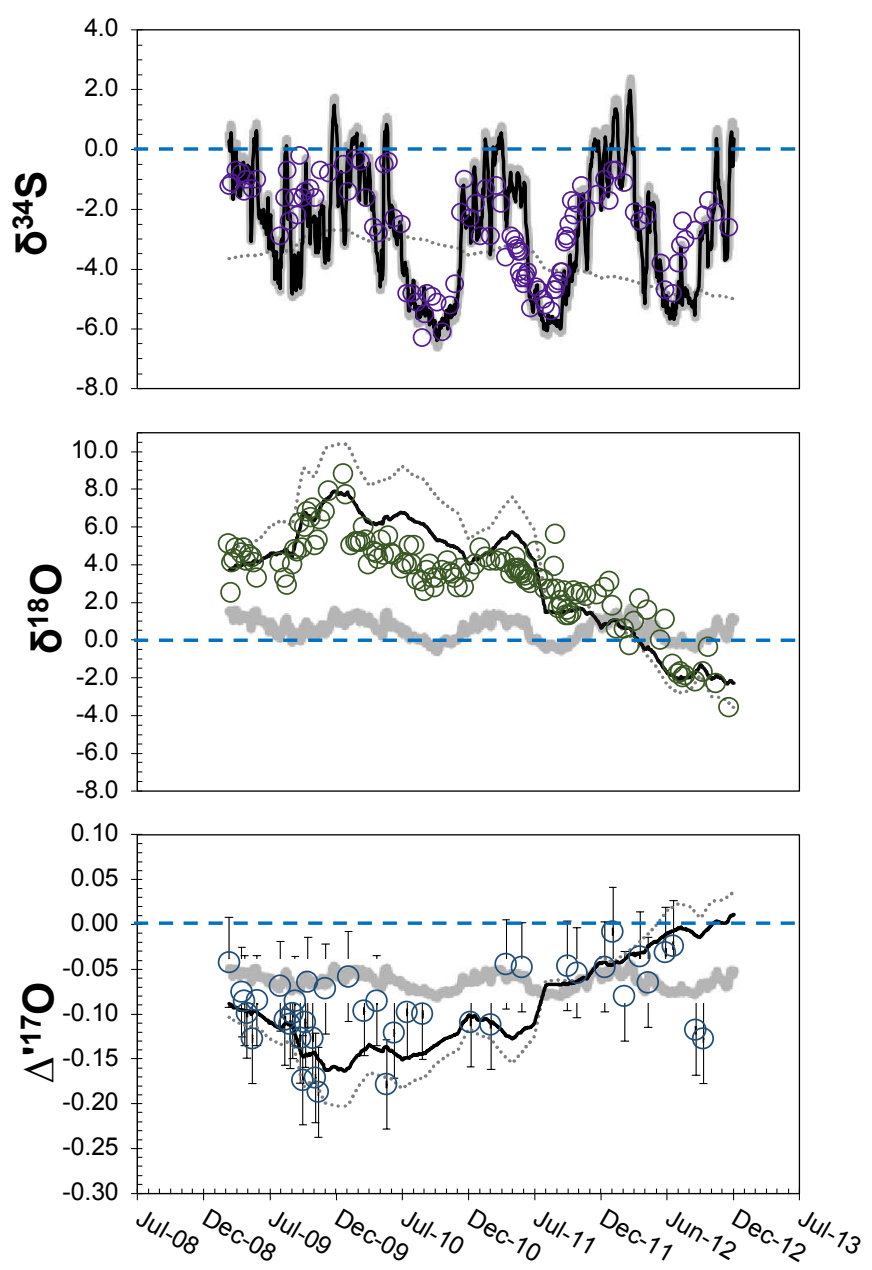

Date

507 Figure 6. Time series of modeled Mississippi River $\delta^{34} \mathrm{~S}_{\mathrm{SO} 4}, \delta^{18} \mathrm{O}_{\mathrm{SO} 4}$, and $\Delta{ }^{17} \mathrm{O}_{\mathrm{SO} 4}$ are shown 508 with measured data. Measured data error bars are shown or are smaller than symbols. The fluxonly model uses a mix of sulfate flux from three Mississippi River sub-basins, the PHDI-only model simulates forcing from overall hydrological conditions for the contiguous United States, and the mixed model incorporates both flux-only and PHDI-only models with further details and 512 discussion given in the main text.

\section{Implications for riverine sulfate}

Mississippi River $\Delta^{, 17} \mathrm{O}_{\mathrm{SO} 4}, \delta^{18} \mathrm{O}_{\mathrm{SO} 4}$, and $\delta^{34} \mathrm{~S}_{\mathrm{SO} 4}$ each reveal their own different

517 perspectives on the Mississippi River system and its response to seasonal changes or year-to-year 
518 weather patterns. Although our Mississippi River study reveals characteristics of riverine sulfate

519 that might be widespread, each river should be considered as a more-or-less unique case, with its 520 own set of processes and sulfur sources dictated by climate, hydrology, and geology. Moreover,

521 in other rivers, anthropogenic influence on sulfate may be expressed by isotopic shifts in the

522 opposite direction, to lower $\delta^{34} \mathrm{~S}_{\mathrm{SO} 4}$ for example, as compared to what is inferred from the

523 Mississippi River. Although not done for this study, measurement of the triple oxygen isotope

524 composition $\left(\delta^{18} \mathrm{O}\right.$ and $\left.\Delta^{, 17} \mathrm{O}\right)$ of not only the dissolved sulfate, but also the river water from the

525 same sample, could enable high resolution sulfate oxygen isotope mass balance calculations,

526 further assist in tracing river water sources such as runoff versus groundwater, and aid

527 interpretations of the sources of sulfate oxygen and sulfate oxidation pathways. Prime targets for

528 follow-up sulfate sulfur and oxygen isotope studies would be the Missouri and Ohio river sub-

529 basins to characterize the loadings of pyrite-derived sulfate from natural and anthropogenic

530 bedrock weathering and mine drainage. Our results add to the calls for reassessing the

531 contribution of pyrite-derived sulfate to global sulfur budgets ${ }^{9}$, especially pyrite-derived sulfate

532 from coal mining ${ }^{15}$, and suggest that the important estimates of natural and anthropogenic global 533 riverine sulfate flux ${ }^{5,73}$ are due for an update.

\section{Acknowledgements}

536 Thanks to Bill Alvey and Tell City High School in Indiana for Ohio River water sampling, Justin

537 Hayles, Stefan Lalonde, Manuel Bellanger, Pierre Sans-Jofre, and the members of Bao group

538 past and present for helpful discussions, and the anonymous reviewers whose constructive

539 comments greatly improved this manuscript. National Science Foundation (EAR-1251824, EAR-

5401312284 to $\mathrm{HB}$ ) provided part of the research fund, and indirect support was received during the 
preparation of this manuscript from the European Union Horizon 2020 research and innovation

program (Marie Sklodowska-Curie grant agreement No 708117 to BK).

\section{Supporting Information Available}

545 Supporting Information includes additional details on methods, modeling, oxygen isotope

546 discussion, and tables of sulfate isotope data, an updated Mississippi River sulfate budget, and

547 model inputs.

\section{References}

550 1. Canfield, D. E., Sulfur isotopes in coal constrain the evolution of the Phanerozoic sulfur 551 cycle. Proc. Nat. Acad. Sci. U.S.A. 2013, 110, (21), 8443-6.

$552 \quad 2 . \quad$ Halevy, I.; Peters, S. E.; Fischer, W. W., Sulfate burial constraints on the Phanerozoic 553 sulfur cycle. Science 2012, 337, (6092), 331-334.

5543 3. Killingsworth, B. A.; Bao, H., Significant Human Impact on the Flux and $\delta 34$ S of Sulfate 555 from the Largest River in North America. Environ. Sci. Technol. 2015, 49, (8), 4851-60.

5564 4. Berner, R. A., Worldwide sulfur pollution of rivers. J. Geophys. Res. 1971, 76, (27), $557 \quad 6597-6600$.

$558 \quad 5 . \quad$ Meybeck, M., Concentrations des eaux fluviales en elements majeurs et apports en 559 solution aux oceans. Rev. Geol. Dyn. Geogr. Phys 1979, 21, (3), 215-246.

$560 \quad$ 6. Ivanov, M.; Grinenko, V.; Rabinovich, A., Sulphur flux from continents to oceans. In The 561 Global Biogeochemical Sulphur Cycle, Ivanov, M. V.; Freney, J. R., Eds. John Wiley \& Sons, 562 Chichester: 1983; pp 331-356.

5637 7. Turchyn, A. V.; Schrag, D. P., Oxygen isotope constraints on the sulfur cycle over the 564 past 10 million years. Science 2004, 303, (5666).

565 8. Karim, A.; Veizer, J., Weathering processes in the Indus River Basin: implications from 566 riverine carbon, sulfur, oxygen, and strontium isotopes. Chem. Geol. 2000, 170, (1), 153-177.

567 9. Calmels, D.; Gaillardet, J.; Brenot, A.; France-Lanord, C., Sustained sulfide oxidation by 568 physical erosion processes in the Mackenzie River basin: Climatic perspectives. Geology 2007, $56935,(11), 1003-1006$.

570 10. Li, X.; Gan, Y.; Zhou, A.; Liu, Y., Relationship between water discharge and sulfate 571 sources of the Yangtze River inferred from seasonal variations of sulfur and oxygen isotopic 572 compositions. J. Geochem. Explor. 2015, 153, 30-39.

573 11. Robinson, B. W.; Bottrell, S. H., Discrimination of sulfur sources in pristine and polluted 574 New Zealand river catchments using stable isotopes. Appl. Geochem. 1997, 12, (3), 305-319.

575 12. Nakano, T.; Tayasu, I.; Wada, E.; Igeta, A.; Hyodo, F.; Miura, Y., Sulfur and strontium 576 isotope geochemistry of tributary rivers of Lake Biwa: implications for human impact on the 577 decadal change of lake water quality. Sci. Tot. Environ. 2005, 345, (1), 1-12. 
578 13. Das, A.; Chung, C. H.; You, C. F., Disproportionately high rates of sulfide oxidation 579 from mountainous river basins of Taiwan orogeny: Sulfur isotope evidence. Geophys. Res. Lett. $580 \quad$ 2012, 39, (12).

$581 \quad$ 14. Torres, M. A.; West, A. J.; Clark, K. E.; Paris, G.; Bouchez, J.; Ponton, C.; Feakins, S. J.; 582 Galy, V.; Adkins, J. F., The acid and alkalinity budgets of weathering in the Andes-Amazon 583 system: Insights into the erosional control of global biogeochemical cycles. Earth Planet. Sci. 584 Lett. 2016, 450, 381-391.

585 15. Raymond, P. A.; Oh, N.-H., Long term changes of chemical weathering products in rivers 586 heavily impacted from acid mine drainage: Insights on the impact of coal mining on regional and global carbon and sulfur budgets. Earth Planet. Sci. Lett. 2009, 284, (1), 50-56. 16. Ingri, J.; Torssander, P.; Andersson, P.; Mörth, C.-M.; Kusakabe, M., Hydrogeochemistry of sulfur isotopes in the Kalix River catchment, northern Sweden. Appl. Geochem. 1997, 12, (4), 483-496.

17. Fitzhugh, R. D.; Furman, T.; Korsak, A. K., Sources of stream sulphate in headwater catchments in Otter Creek Wilderness, West Virginia, USA. Hydrol. Processes 2001, 15, (4), 541-556.

18. Björkvald, L.; Giesler, R.; Laudon, H.; Humborg, C.; Mörth, C.-M., Landscape variations in stream water SO42- and $834 \mathrm{~S}$ SO4 in a boreal stream network. Geochim. Cosmochim. Acta 2009, 73, (16), 4648-4660.

19. Stam, A.; Mitchell, M.; Krouse, H.; Kahl, J., Stable sulfur isotopes of sulfate in precipitation and stream solutions in a northern hardwood watershed. Water Resour. Res. 1992,

600 20. Alewell, C.; Mitchell, M.; Likens, G.; Krouse, H., Sources of stream sulfate at the 601 Hubbard Brook Experimental Forest: Long-term analyses using stable isotopes. Biogeochemistry 602 1999, 44, (3), 281-299.

603 21. Novák, M.; Kirchner, J. W.; Groscheová, H.; Havel, M.; Černý, J.; Krejčí, R.; Buzek, F., 604 Sulfur isotope dynamics in two central european watersheds affected by high atmospheric deposition of SOx. Geochim. Cosmochim. Acta 2000, 64, (3), 367-383.

609 23. Otero, N.; Soler, A.; Canals, À., Controls of $\delta 34 \mathrm{~S}$ and $\delta 18 \mathrm{O}$ in dissolved sulphate:

610 Learning from a detailed survey in the Llobregat River (Spain). Appl. Geochem. 2008, 23, (5),

611 1166-1185.

612 24. Rock, L.; Mayer, B., Identifying the influence of geology, land use, and anthropogenic

613 activities on riverine sulfate on a watershed scale by combining hydrometric, chemical and

614 isotopic approaches. Chem. Geol. 2009, 262, (3), 121-130.

615 25. Böhlke, J. K.; Michel, R. L., Contrasting residence times and fluxes of water and sulfate

616 in two small forested watersheds in Virginia, USA. Sci. Tot. Environ. 2009, 407, (14), 4363-

6174377.

618 26. Tichomirowa, M.; Heidel, C.; Junghans, M.; Haubrich, F.; Matschullat, J., Sulfate and

619 strontium water source identification by O, S and Sr isotopes and their temporal changes (1997-

620 2008) in the region of Freiberg, central-eastern Germany. Chem. Geol. 2010, 276, (1-2), 104-

621118.

622 27. NASA/JPL Shaded Relief with Height as Color, North America.

623 http://photojournal.jpl.nasa.gov/catalog/PIA03377 
624 28. Meybeck, M.; Ragu, A. GEMS/GLORI world river discharge database.

625 http://doi.pangaea.de/10.1594/PANGAEA.804574

626 29. Goolsby, D. A.; Battaglin, W. A.; Lawrence, G. B.; Artz, R. S.; Aulenbach, B. T.;

627 Hooper, R. P.; Keeney, D. R.; Stensland, G. J. Flux and sources of nutrients in the Mississippi-

628 Atchafalaya River Basin; National Oceanic and Atmospheric Administration National Ocean

629 Service Coastal Ocean Program: 1999.

$63030 . \quad$ Turner, R. E.; Rabalais, N. N., Linking landscape and water quality in the Mississippi

631 River Basin for 200 years. BioScience 2003, 53, (6), 563-572.

632 31. U.S. Geological Survey National Water Information System data available on the World

633 Wide Web (Water Data for the Nation). http://waterdata.usgs.gov/nwis/

634 32. U.S. Army Corps of Engineers Mississippi River Basin: Stage Data.

635 http://www2.mvn.usace.army.mil/eng/edhd/wcontrol/miss.asp

636 33. Bao, H., Purifying barite for oxygen isotope measurement by dissolution and

637

638 reprecipitation in a chelating solution. Anal. Chem. 2006, 78, (1), 304-309.

34. Bao, H.; Cao, X.; Hayles, J. A., Triple Oxygen Isotopes: Fundamental Relationships and Applications. Annu. Rev. Earth Planet. Sci. 2016, 44, (1).

$640 \quad 35 . \quad$ R Core Team $R$ : A language and environment for statistical computing. $R$ package version 3.1.1, Vienna, 2013.

36. National Oceanic and Atmospheric Administration (NOAA) National Centers for Environmental Information Climate at a Glance. http://www.ncdc.noaa.gov/cag/time-series/us/ 37. Ruhl, L.; Vengosh, A.; Dwyer, G. S.; Hsu-Kim, H.; Deonarine, A.; Bergin, M.; Kravchenko, J., Survey of the Potential Environmental and Health Impacts in the Immediate Aftermath of the Coal Ash Spill in Kingston, Tennessee. Environ. Sci. Technol. 2009, 43, (16), 6326-6333.

648 38. Harkness, J. S.; Sulkin, B.; Vengosh, A., Evidence for Coal Ash Ponds Leaking in the 649 Southeastern United States. Environ. Sci. Technol. 2016.

650 39. Garrity, C. P., Database of the Geologic Map of North America-Adapted from the Map by JC Reed, Jr. and others (2005). 2009.

40. Gautier, D. L., Cretaceous shales from the western interior of North America: Sulfur/carbon ratios and sulfur-isotope composition. Geology 1986, 14, (3), 225-228. 41. Fry, B.; Allen, Y. C., Stable isotopes in zebra mussels as bioindicators of river-watershed linkages. River Res. Appl. 2003, 19, (7), 683-696. million years. Science 2012, 337, (6092), 334-336.

659 J. Geophys. Res.: Oceans 1983, 88, (C6), 3703-3717.

660 44. Berndt, M.; Bavin, T., On the Cycling of Sulfur and Mercury in the St. Louis River 661 Watershed, Northeastern Minnesota. 2012.

662 45. Brenot, A.; Carignan, J.; France-Lanord, C.; Benoît, M., Geological and land use control 663 on $\delta 34 \mathrm{~S}$ and $\delta 18 \mathrm{O}$ of river dissolved sulfate: The Moselle river basin, France. Chem. Geol. 2007, 664 244, (1), 25-41.

665 46. Global Network of Isotopes in Rivers (GNIR) Mississippi River 180 data measured by 666 the USGS Reston laboratory, 1984-1987. http://www-

667 naweb.iaea.org/napc/ih/IHS resources gnir.html

668 47. Young, E. D.; Yeung, L. Y.; Kohl, I. E., On the $\Delta 17$ O budget of atmospheric O2.

669 Geochim. Cosmochim. Acta 2014, 135, 102-125. 
48. Van Stempvoort, D.; Krouse, H. In Controls of $\delta 18 O$ in sulfate, Environmental geochemistry of Sulfide Oxidation. Washington DC, American Chemical Society, Symposium Series, 1994; ACS Publications: 1994; pp 446-480. 49. Kohl, I.; Bao, H. M., Triple-oxygen-isotope determination of molecular oxygen incorporation in sulfate produced during abiotic pyrite oxidation ( $\mathrm{pH}=2-11)$. Geochim. Cosmochim. Acta 2011, 75, (7), 1785-1798. 50. Kendall, C.; Coplen, T. B., Distribution of oxygen-18 and deuterium in river waters across the United States. Hydrol. Processes 2001, 15, (7), 1363-1393. 51. Turchyn, A. V.; Tipper, E. T.; Galy, A.; Lo, J.-K.; Bickle, M. J., Isotope evidence for secondary sulfide precipitation along the Marsyandi River, Nepal, Himalayas. Earth Planet. Sci. Lett. 2013, 374, 36-46. 52. Mayer, B., Assessing sources and transformations of sulphate and nitrate in the hydrosphere using isotope techniques. In Isotopes in the Water Cycle, Springer: 2005; pp 67-89. 53. Taylor, B. E.; Wheeler, M. C.; Nordstrom, D. K., Isotope composition of sulphate in acid mine drainage as measure of bacterial oxidation. Nature 1984, 308, (5959), 538.

54. Balci, N.; Shanks, W. C.; Mayer, B.; Mandernack, K. W., Oxygen and sulfur isotope systematics of sulfate produced by bacterial and abiotic oxidation of pyrite. Geochim. Cosmochim. Acta 2007, 71, (15), 3796-3811. isotope fractionations record different intracellular steps of microbial sulfate reduction. Geochim. Cosmochim. Acta 2017, 203, 364-380.

56. Mills, J. V.; Antler, G.; Turchyn, A. V., Geochemical evidence for cryptic sulfur cycling in salt marsh sediments. Earth Planet. Sci. Lett. 2016, 453, 23-32.

57. $\quad$ Likens, G.; Driscoll, C.; Buso, D.; Mitchell, M.; Lovett, G.; Bailey, S.; Siccama, T.; Reiners, W.; Alewell, C., The biogeochemistry of sulfur at Hubbard Brook. Biogeochemistry 2002, 60, (3), 235-316.

58. Miles, G. R.; Mitchell, M. J.; Mayer, B.; Likens, G.; Welker, J., Long-term analysis of Hubbard Brook stable oxygen isotope ratios of streamwater and precipitation sulfate. Biogeochemistry 2011, 111, (1-3), 443-454.

59. Coplen, T. B.; Kendall, C. Stable hydrogen and oxygen isotope ratios for selected sites of the US Geological Survey's NASQAN and benchmark surface-water networks; GEOLOGICAL SURVEY RESTON VA: 2000.

60. Winston, W.; Criss, R., Oxygen isotope and geochemical variations in the Missouri River. Environ. Geol. 2003, 43, (5), 546-556.

61. Palmer, W. C., Meteorological drought. US Department of Commerce, Weather Bureau Washington, DC, USA: 1965; Vol. 30.

62. Van Loon, A. F., Hydrological drought explained. Wiley Interdiscip. Rev.: Water 2015, 2 , (4), 359-392.

63. Heim Jr, R. R., A review of twentieth-century drought indices used in the United States. Bull. Am. Meteorol. Soc. 2002, 83, (8), 1149.

64. Wankel, S. D.; Bradley, A. S.; Eldridge, D. L.; Johnston, D. T., Determination and application of the equilibrium oxygen isotope effect between water and sulfite. Geochim. Cosmochim. Acta 2014, 125, 694-711.

65. Taylor, B. E.; Wheeler, M. C., Sulfur- and Oxygen-Isotope Geochemistry of Acid Mine Drainage in the Western United States. In Environmental Geochemistry of Sulfide Oxidation, American Chemical Society: 1993; Vol. 550, pp 481-514. 
716 66. Johnson, C. A.; Mast, M. A.; Kester, C. L., Use of 17O/16O to trace atmospherically 717 deposited sulfate in surface waters: A case study in Alpine watersheds in the Rocky Mountains.

718 Geophys. Res. Lett. 2001, 28, (23), 4483-4486.

719 67. Bao, H., Sulfate: A time capsule for Earth's O2, O3, and H2O. Chem. Geol. 2015, 395, $720 \quad 108-118$.

721 68. Jenkins, K. A.; Bao, H., Multiple oxygen and sulfur isotope compositions of atmospheric 722 sulfate in Baton Rouge, LA, USA. Atmos. Environ. 2006, 40, (24), 4528-4537.

723 69. Li, X.; Bao, H.; Gan, Y.; Zhou, A.; Liu, Y., Multiple oxygen and sulfur isotope 724 compositions of secondary atmospheric sulfate in a mega-city in central China. Atmos. Environ. 725 2013, 81, 591-599.

726 70. Savarino, J.; Lee, C. C.; Thiemens, M. H., Laboratory oxygen isotopic study of sulfur

727 (IV) oxidation: Origin of the mass - independent oxygen isotopic anomaly in atmospheric 728 sulfates and sulfate mineral deposits on Earth. J. Geophys. Res.: Atmos. 2000, 105, (D23), 729 29079-29088.

730 71. Luz, B.; Barkan, E., Variations of $17 \mathrm{O} / 16 \mathrm{O}$ and $18 \mathrm{O} / 16 \mathrm{O}$ in meteoric waters. Geochim. 731 Cosmochim. Acta 2010, 74, (22), 6276-6286.

732 72. Tichomirowa, M.; Junghans, M., Oxygen isotope evidence for sorption of molecular 733 oxygen to pyrite surface sites and incorporation into sulfate in oxidation experiments. Appl. 734 Geochem. 2009, 24, (11), 2072-2092.

735 73. Berner, E. K.; Berner, R. A., Global environment: water, air, and geochemical cycles. 736 Princeton University Press: 2012. 


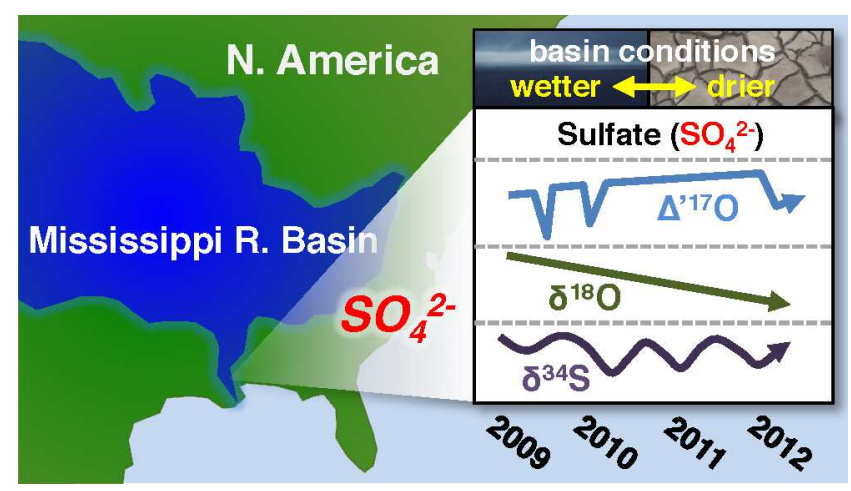




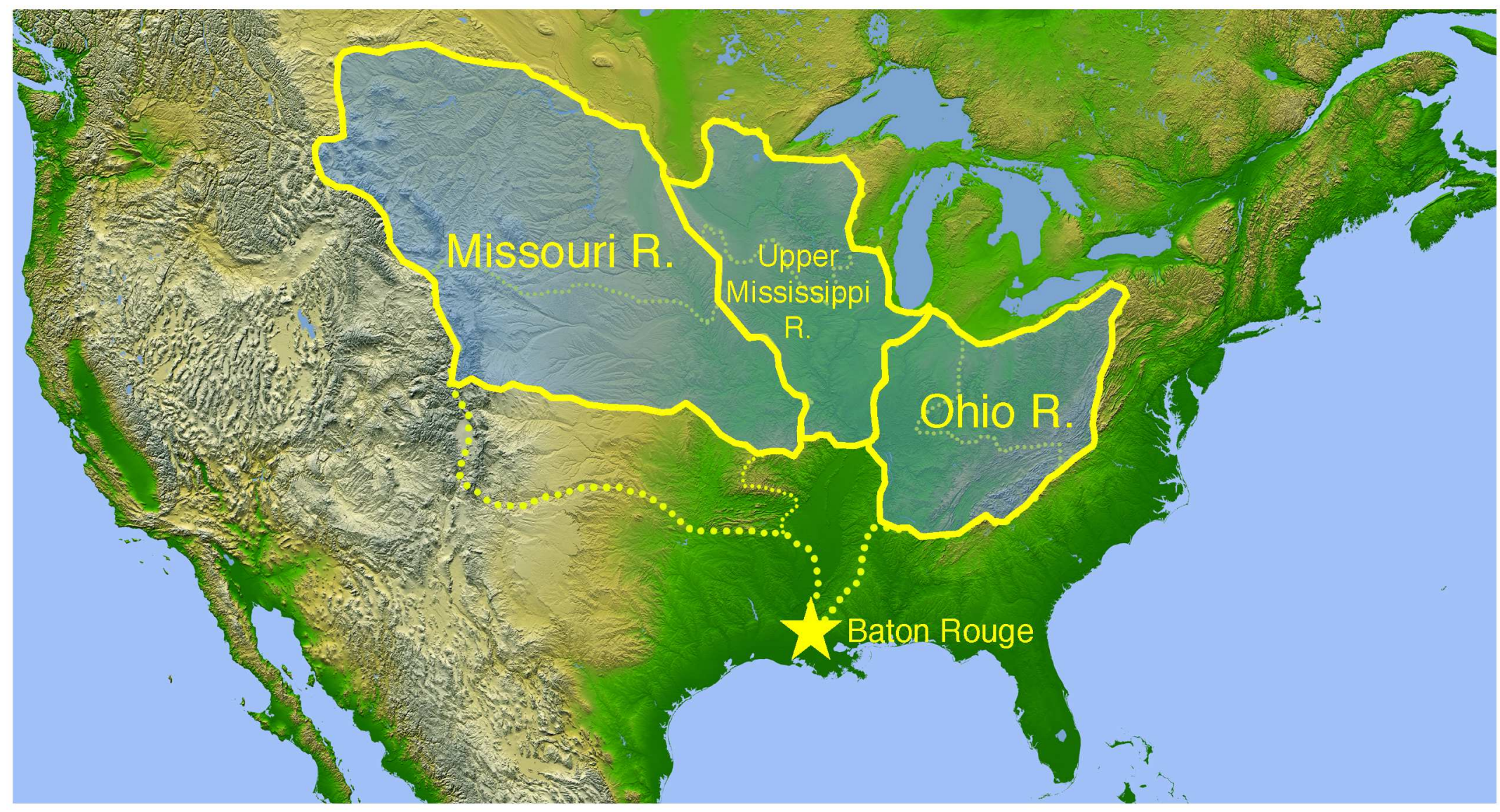




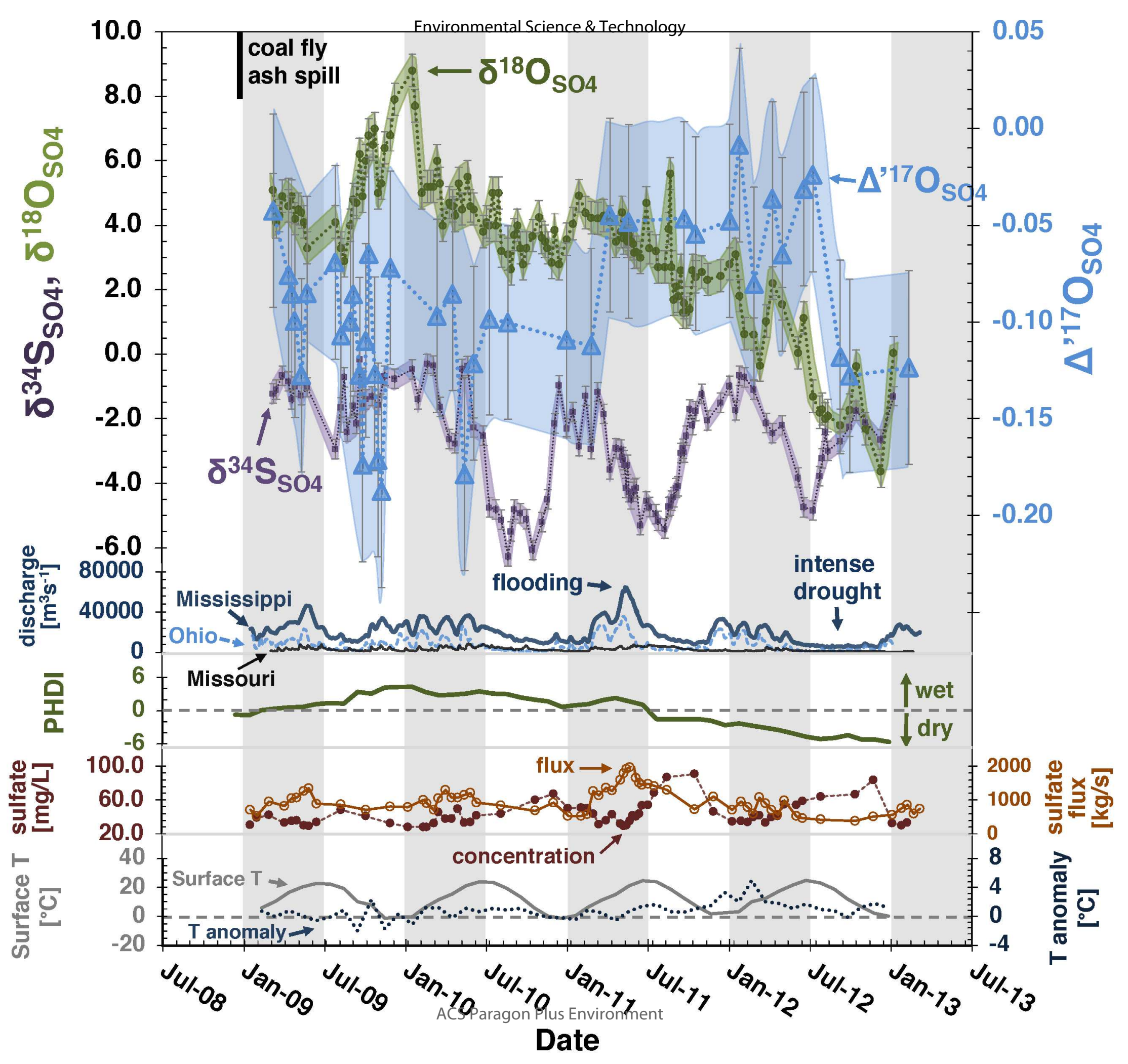




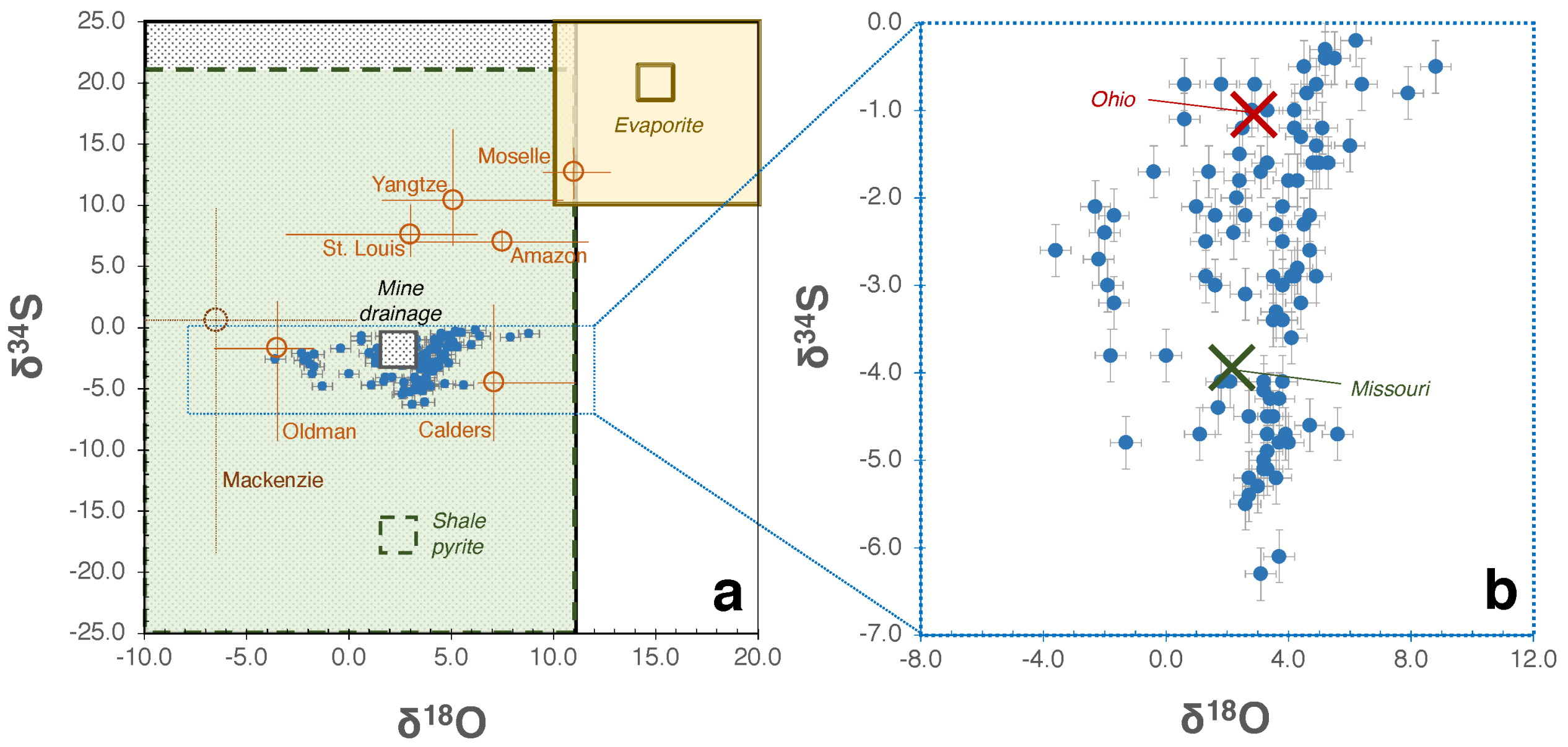




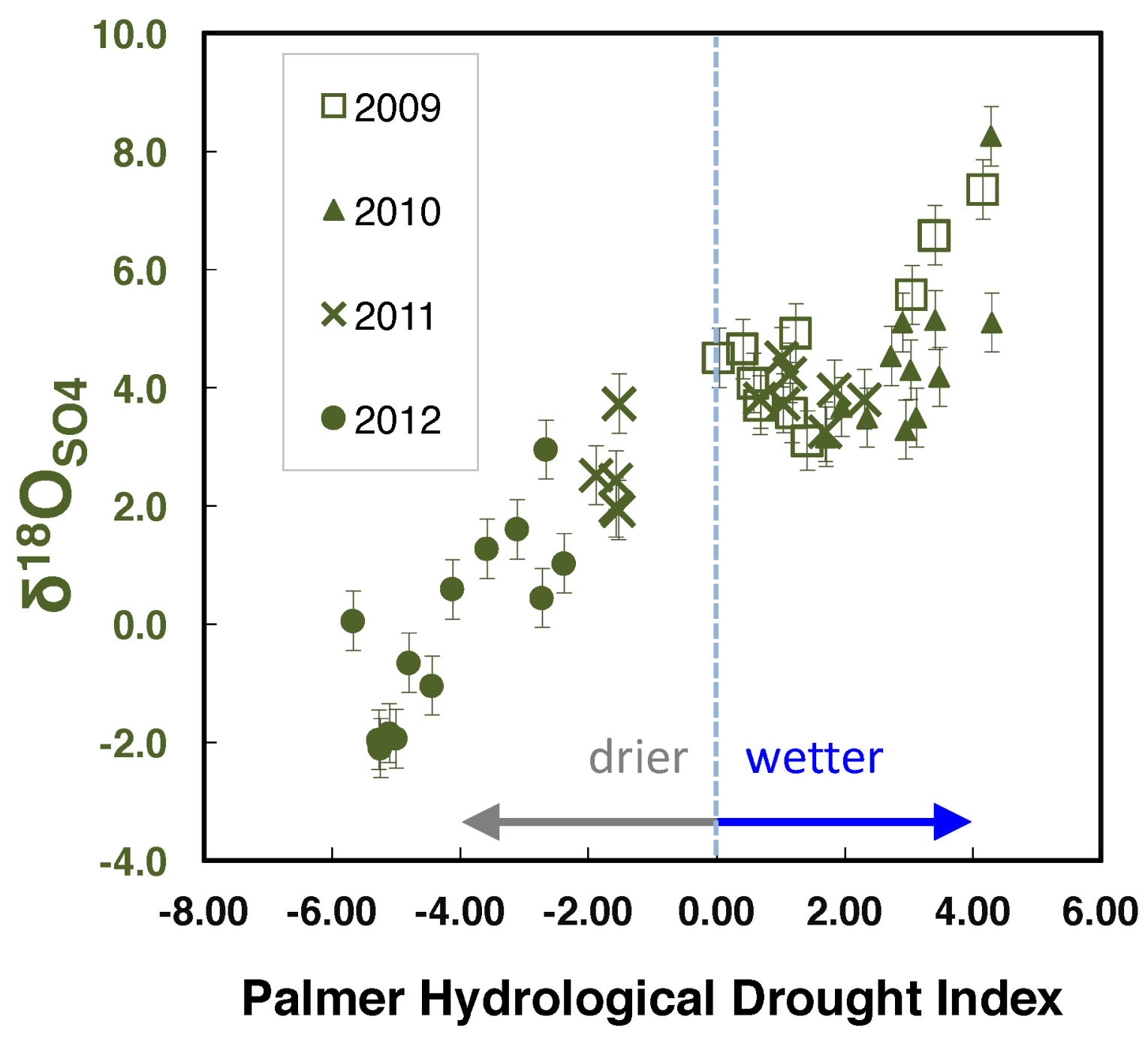




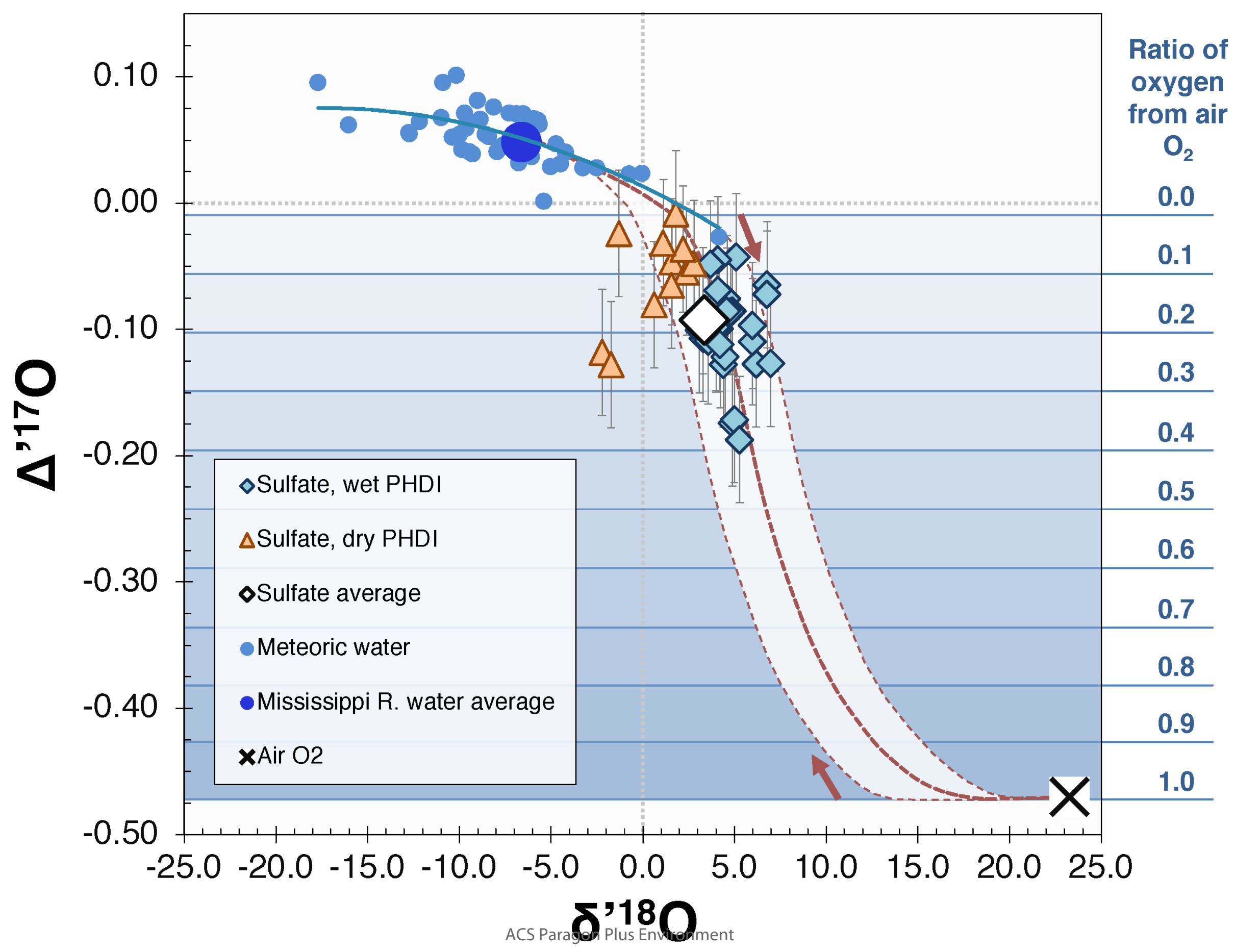



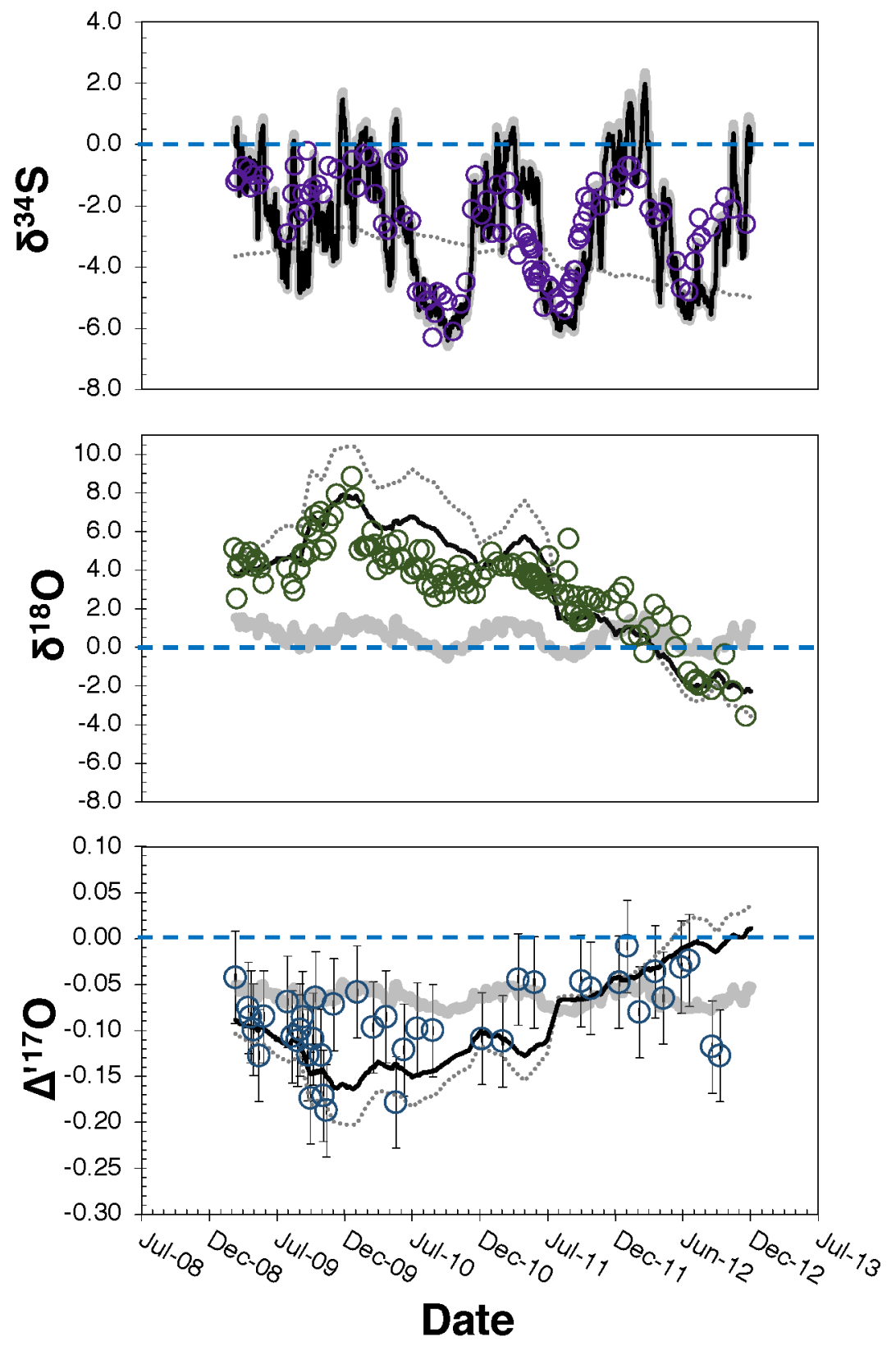

\begin{tabular}{|clll|}
\hline O & Measured data & $\ldots . . .$. & PHDI-only model \\
& Flux-only model & - & Mixed model \\
\hline
\end{tabular}

